\title{
Article \\ Effect of Organic Amendment Addition on Soil Properties, Greenhouse Gas Emissions and Grape Yield in Semi-Arid Vineyard Agroecosystems
}

\author{
Antonio Marín-Martínez ${ }^{1}$, Alberto Sanz-Cobeña ${ }^{2} \mathbb{D}, M^{\text {a }}$ Angeles Bustamante $^{1} \mathbb{D}$, Enrique Agulló ${ }^{1}$ and \\ Concepción Paredes $1, *$ (D) \\ 1 Centro de Investigación e Innovación Agroalimentaria y Agroambiental (CIAGRO-UMH), \\ Miguel Hernandez University, EPS-Orihuela, Ctra Beniel Km. 3.2, 03312 Orihuela, Spain; \\ antonio_jose_mm@hotmail.com (A.M.-M.); marian.bustamante@umh.es (M.A.B.); \\ enrique.agullo@umh.es (E.A.) \\ 2 CEIGRAM, ETSI Agrónomos, Technical University of Madrid, Ciudad Universitaria, 28040 Madrid, Spain; \\ a.sanz@upm.es \\ * Correspondence: c.paredes@umh.es
}

check for

updates

Citation: Marín-Martínez, A.; Sanz-Cobeña, A.; Bustamante, M.A.; Agulló, E.; Paredes, C. Effect of Organic Amendment Addition on Soil Properties, Greenhouse Gas Emissions and Grape Yield in Semi-Arid Vineyard Agroecosystems. Agronomy 2021, 11, 1477. https:// doi.org/10.3390/agronomy11081477

Academic Editor: Enrique Eymar

Received: 16 June 2021

Accepted: 20 July 2021

Published: 25 July 2021

Publisher's Note: MDPI stays neutral with regard to jurisdictional claims in published maps and institutional affiliations.

Copyright: (c) 2021 by the authors. Licensee MDPI, Basel, Switzerland. This article is an open access article distributed under the terms and conditions of the Creative Commons Attribution (CC BY) license (https:/ / creativecommons.org/licenses/by/ $4.0 /)$.

\begin{abstract}
In semi-arid vineyard agroecosystems, highly vulnerable in the context of climate change, the soil organic matter $(\mathrm{OM})$ content is crucial to the improvement of soil fertility and grape productivity. The impact of $\mathrm{OM}$, from compost and animal manure, on soil properties (e.g., pH, oxidisable organic $\mathrm{C}$, organic $\mathrm{N}, \mathrm{NH}_{4}{ }^{+}-\mathrm{N}$ and $\mathrm{NO}_{3}{ }^{-}-\mathrm{N}$ ), grape yield and direct greenhouse gas (GHG) emission in vineyards was assessed. For this purpose, two wine grape varieties were chosen and managed differently: with a rain-fed non-trellising vineyard of Monastrell, a drip-irrigated trellising vineyard of Monastrell and a drip-irrigated trellising vineyard of Cabernet Sauvignon. The studied fertiliser treatments were without organic amendments (C), sheep/goat manure (SGM) and distillery organic waste compost (DC). The SGM and DC treatments were applied at a rate of $4600 \mathrm{~kg} \mathrm{ha}^{-1}$ (fresh weight, FW) and $5000 \mathrm{~kg} \mathrm{ha}^{-1} \mathrm{FW}$, respectively. The use of organic amendments improved soil fertility and grape yield, especially in the drip-irrigated trellising vineyards. Increased $\mathrm{CO}_{2}$ emissions were coincident with higher grape yields and manure application (maximum $\mathrm{CO}_{2}$ emissions $=1518 \mathrm{mg} \mathrm{C}-\mathrm{CO}_{2} \mathrm{~m}^{-2} \mathrm{~d}^{-1}$ ). In contrast, $\mathrm{N}_{2} \mathrm{O}$ emissions, mainly produced through nitrification, were decreased in the plots showing higher grape production (minimum $\mathrm{N}_{2} \mathrm{O}$ emissions $=-0.090 \mathrm{mg} \mathrm{N}_{2} \mathrm{O}-\mathrm{N} \mathrm{m}^{-2} \mathrm{~d}^{-1}$ ). In all plots, the $\mathrm{CH}_{4}$ fluxes were negative during most of the experiment $\left(-1.073-0.403 \mathrm{mg} \mathrm{CH}_{4}-\mathrm{C} \mathrm{m}^{-2} \mathrm{~d}^{-1}\right)$, indicating that these ecosystems can represent a significant sink for atmospheric $\mathrm{CH}_{4}$. According to our results, the optimal vineyard management, considering soil properties, yield and GHG mitigation together, was the use of compost in a drip-irrigated trellising vineyard with the grape variety Monastrell.
\end{abstract}

Keywords: Mediterranean vineyard systems; compost; animal manure; soil fertility; grape yield; GHG emission; irrigation

\section{Introduction}

Vineyard soils covered a total area of 7.5 Mha worldwide in 2016. In that year, Spain was the country with the greatest extension of vineyards $(975,270 \mathrm{ha})$ and had a wine production of around $40 \times 10^{6} \mathrm{hL}$ [1]. Most of the Spanish vineyards are concentrated in the Mediterranean basin, now highly vulnerable in the context of climate change [2], with viticulture being a significant economic sector (the wine production generated an income of $€ 4.8$ billion in 2016) [3] and part of the socio-cultural heritage in this zone. Appropriate soil management practices are needed to ensure the environmental sustainability of the viticulture sector, a situation increasingly demanded by consumers [4].

The management of the vineyards includes various agricultural practices affecting soil functions. The most common soil management techniques in Mediterranean vineyards 
consist of tillage for mechanical weeding, which keeps the soil between the vines uncovered throughout the year. This practice is intended to avoid competition for water between weeds and grapevines [5] and it also contributes to the modification of soil physical and biological properties and to the decrease in the soil organic matter (SOM) content [6]. Irrigation is also a pivotal management strategy to improve and regulate grape yield and quality, especially in semi-arid areas, typical under Mediterranean climates [7]. Irrigation might also affect the soil microbial communities and root activity [8]. Currently, the vinetraining system is being transformed from the traditional "bush vine" method, without physical support systems, to trellis systems, where the vines grow attached to posts, stakes, wires or other structures. This change has facilitated the mechanisation of certain vineyard tasks such as pruning, irrigation, pesticide and/or fertiliser application and the grapes harvest [9]. However, the compaction and sealing of the soil are enhanced by the passage of the machinery [10]. Synthetic $\mathrm{N}$ fertilisers are normally used in conventional vineyard agroecosystems. Excessive application of fertiliser can reduce both the must quality [11] and the SOM content [12,13]. Inappropriate application of $\mathrm{N}$ fertiliser leads also to the direct emission of greenhouse gases (GHGs), such as nitrous oxide $\left(\mathrm{N}_{2} \mathrm{O}\right)$, and the release of other reactive $\mathrm{N}$ forms with negative socio-environmental impacts (e.g., nitrate in water bodies and ammonia in the atmosphere) [2]. The emissions of $\mathrm{N}_{2} \mathrm{O}$ in Mediterranean-climate cropping systems are influenced by the irrigation management, the fertiliser type (liquid or solid organic, organic-synthetic mixtures and synthetic fertilisers), the $\mathrm{N}$ application rate, the soil mineral $\mathrm{N}$, total organic carbon and dissolved organic carbon contents, the pore spaces filled with soil water and the temperature, $\mathrm{pH}$ and texture [14]. In general, $\mathrm{N}_{2} \mathrm{O}$ fluxes are low in Mediterranean ecosystems due to their very low $\mathrm{N}$ and water inputs [15]. The different agricultural practices carried out as part of vineyard management may also influence the direct emissions of other GHGs such as $\mathrm{CO}_{2}$ and $\mathrm{CH}_{4}[8,13,14]$. In the case of Mediterranean ecosystems, the seasonal cycles of drought and drying and rewetting are important factors in the emission of $\mathrm{CO}_{2}$ from the soil [16]. Moreover, tillage increases the soil $\mathrm{CO}_{2}$ emissions due to the stimulation of microbial activity by soil aeration and the breakdown of soil macroaggregates [17], with the release of labile OM formerly protected from soil microbes within the macroaggregates [18]. It has been reported that the irrigation of the soil and the use of organic amendments can trigger $\mathrm{CO}_{2}$ and $\mathrm{N}_{2} \mathrm{O}$ emissions $[8,19]$. However, the use of stabilised and mature organic amendments can maintain and even increase $\mathrm{C}$ stocks in soils and improve $\mathrm{N}$ availability to crops. Regarding $\mathrm{CH}_{4}$, the oxidation of this gas in the soil is mainly controlled by its diffusion, the water content of the soil being the main factor that determines the potential of the ecosystem as a sink for $\mathrm{CH}_{4}$. Therefore, in Mediterranean ecosystems, with precipitation in winter and dry and warm summers, the oxidation of $\mathrm{CH}_{4}$ is favoured throughout the year [16].

Additionally, the intensive use of some agricultural practices is the main reason for the high erodibility of most Mediterranean vineyard soils. The use of organic amendments, such as vegetative residue mulch [20], compost and manure [12,13,21,22], vine shoot pruning [12], spent mushroom substrate [23] and vermicompost [24], can be a viable option to improve the soil fertility and quality and the grape production. This is due to their capacity to supply nutrients, improve the microbiological activity of the soil, increase its cation exchange, infiltration and water retention capacities, decrease the apparent density and promote soil aggregation. Moreover, the use of organic wastes, as by-products of the Mediterranean food-chain, can contribute to the sustainability of the viticulture sector by reducing the use of synthetic fertiliser through a return of nutrients, thus promoting the operation of this agro-industrial sector as part of a circular economy approach [25].

Hence, based on the above-mentioned considerations, the objective of this study was to evaluate the effect of the organic fertiliser type on the soil $\mathrm{C}$ and $\mathrm{N}$ mineralisation dynamics, grape yield and direct GHG emissions of Mediterranean wine grape vineyards managed with different practices - in terms of the training system, irrigation, $\mathrm{N}$ fertiliser and grape variety-over one full growing season. 


\section{Materials and Methods}

\subsection{Study Area and Soil Characteristics}

This study was conducted during the 2014 crop season in three commercial wine grape vineyard plots close to Monovar, in the Vinalopo region (Alicante-south-eastern Spain; 38027' $4^{\prime \prime} \mathrm{N}, 0 \mathrm{o} 54^{\prime} 56^{\prime \prime} \mathrm{W}$; elevation $392 \mathrm{~m}$ a.s.l.). The area has a semi-arid continental Mediterranean climate, with a mean annual temperature of $15.1^{\circ} \mathrm{C}$, mean annual rainfall of $345 \mathrm{~mm}$ and an annual Penman-Monteith Evapotranspiration of $1400 \mathrm{~mm}$ (average value based on data collected from 2005 to 2015 by [26]). Figure 1 shows the precipitation and air temperatures recorded during the period studied. The soil in this area has a sandy-loam texture and is classified as a Xeric Haplocalcids [27]. The plots studied had soils with similar characteristics, with $8 \%-14 \%$ silt, $9 \%-15 \%$ clay and $71 \%-81 \%$ sand. They were calcareous (118-189 $\mathrm{g}$ of active $\mathrm{CaCO}_{3} \mathrm{~kg}^{-1}$ ) and had values of $\mathrm{pH}$ and electrical conductivity (EC) in water extracts of $8.3-8.4$ and $0.26-0.28 \mathrm{dS} \mathrm{m}^{-1}$, respectively. The oxidisable organic carbon (oxidisable OC) contents were low $\left(3.3-4.4 \mathrm{~g} \mathrm{~kg}^{-1}\right.$ ).

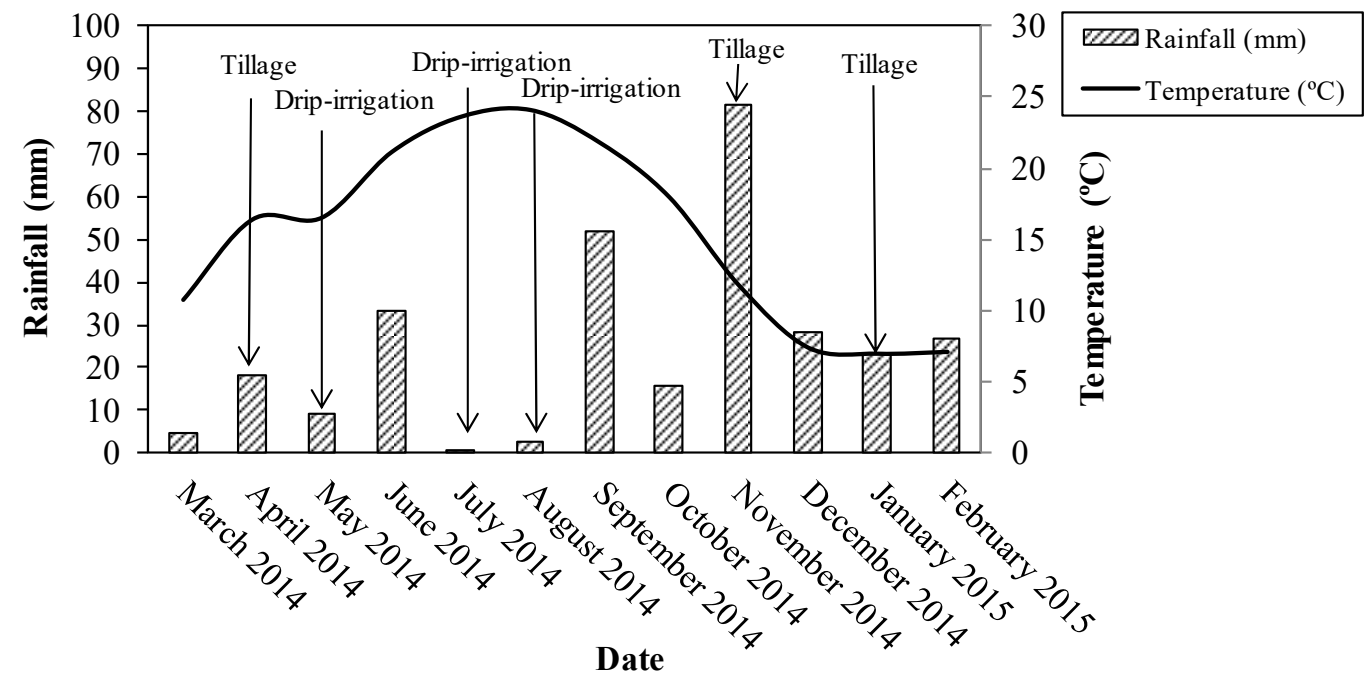

Figure 1. Mean monthly temperature and rainfall at the experimental site and the main agricultural practices carried out during the experimental period (March 2014-February 2015).

The plots had two different varieties of grape (Vitis vinifera L.), namely 15-year-old Monastrell and 10-year-old Cabernet Sauvignon, grafted onto 110 Richter rootstock. The training systems were a bilateral cordon trellised to a three-wire vertical system (dripirrigated) and the traditional "bush vine" method, without a system of support (rain-fed vineyard). The plantation densities were 2000 and 2300 vines per hectare for non-trellised and trellised grapevines, respectively.

\subsection{Experimental Design}

This work involved the study of three treatments, with three replicate sub-plots per treatment (each containing 10 planted vines) set up in a completely randomised design. The treatments were two organic amendments, sheep/goat manure (SGM) and distillery organic waste compost (DC), along with an unfertilised control (C). Table 1 shows the physico-chemical properties and chemical composition of the organic materials used. The application of the amendments was adjusted to provide $170 \mathrm{~kg} \mathrm{ha}^{-1}$ of $\mathrm{N}$, the rate allowed for organic $\mathrm{N}$ amendments in zones vulnerable to groundwater pollution by nitrate from agricultural sources [28]. Based on this, the application rate was $4600 \mathrm{~kg} \mathrm{ha}^{-1} \mathrm{FW}$ of SGM and $5000 \mathrm{~kg} \mathrm{ha}^{-1} \mathrm{FW}$ of DC. These amendments were applied to the surface and incorporated into the soil to a depth of $30 \mathrm{~cm}$ in March, using a chisel plough. Synthetic fertiliser was not applied during the experiment and only three supplemental drip irrigations (100 mm each) were carried out—on 15 May, 21 July and 25 August 2014—in the plots with 
trellised grapevines. All plots had reduced tillage and the usual pesticide treatments were applied (Figures 1 and 2).

Table 1. Physico-chemical properties and chemical composition of the organic materials used in the experiment.

\begin{tabular}{ccc}
\hline Parameter $^{\text {a }}$ & SGM & DC \\
\hline $\mathrm{pH}$ & $7.34 \pm 0.01$ & $7.79 \pm 0.04$ \\
Electrical conductivity $\left(\mathrm{dS} \mathrm{m}^{-1}\right)$ & $10.83 \pm 0.12$ & $4.92 \pm 0.11$ \\
Organic matter $(\%)$ & $47.5 \pm 0.6$ & $61.5 \pm 0.4$ \\
Total organic C $\left(\mathrm{g} \mathrm{kg}^{-1}\right)$ & $224.3 \pm 3.1$ & $436.0 \pm 9.3$ \\
Total $\left(\mathrm{g} \mathrm{kg}^{-1}\right)$ & $37.0 \pm 0.5$ & $21.9 \pm 0.7$ \\
$\mathrm{P}\left(\mathrm{g} \mathrm{kg}^{-1}\right)$ & $2.04 \pm 0.03$ & $2.45 \pm 0.09$ \\
$\mathrm{Na}\left(\mathrm{g} \mathrm{kg}^{-1}\right)$ & $7.1 \pm 0.3$ & $4.1 \pm 0.2$ \\
$\mathrm{~K}\left(\mathrm{~g} \mathrm{~kg}^{-1}\right)$ & $9.6 \pm 0.1$ & $23.7 \pm 0.3$ \\
$\mathrm{Fe}\left(\mathrm{mg} \mathrm{kg}^{-1}\right)$ & $6777 \pm 1$ & $4304 \pm 2$ \\
$\mathrm{Cu}\left(\mathrm{mg} \mathrm{kg}^{-1}\right)$ & $71 \pm 0$ & $61 \pm 1$ \\
$\mathrm{Mn}\left(\mathrm{mg} \mathrm{kg}^{-1}\right)$ & $436 \pm 1$ & $174 \pm 0$ \\
$\mathrm{Zn}\left(\mathrm{mg} \mathrm{kg}^{-1}\right)$ & $230 \pm 0$ & $283 \pm 1$ \\
\hline
\end{tabular}

a Values on a dry matter basis. Values reported as mean \pm standard error. SGM: sheep/goat manure; DC: distillery organic waste compost.
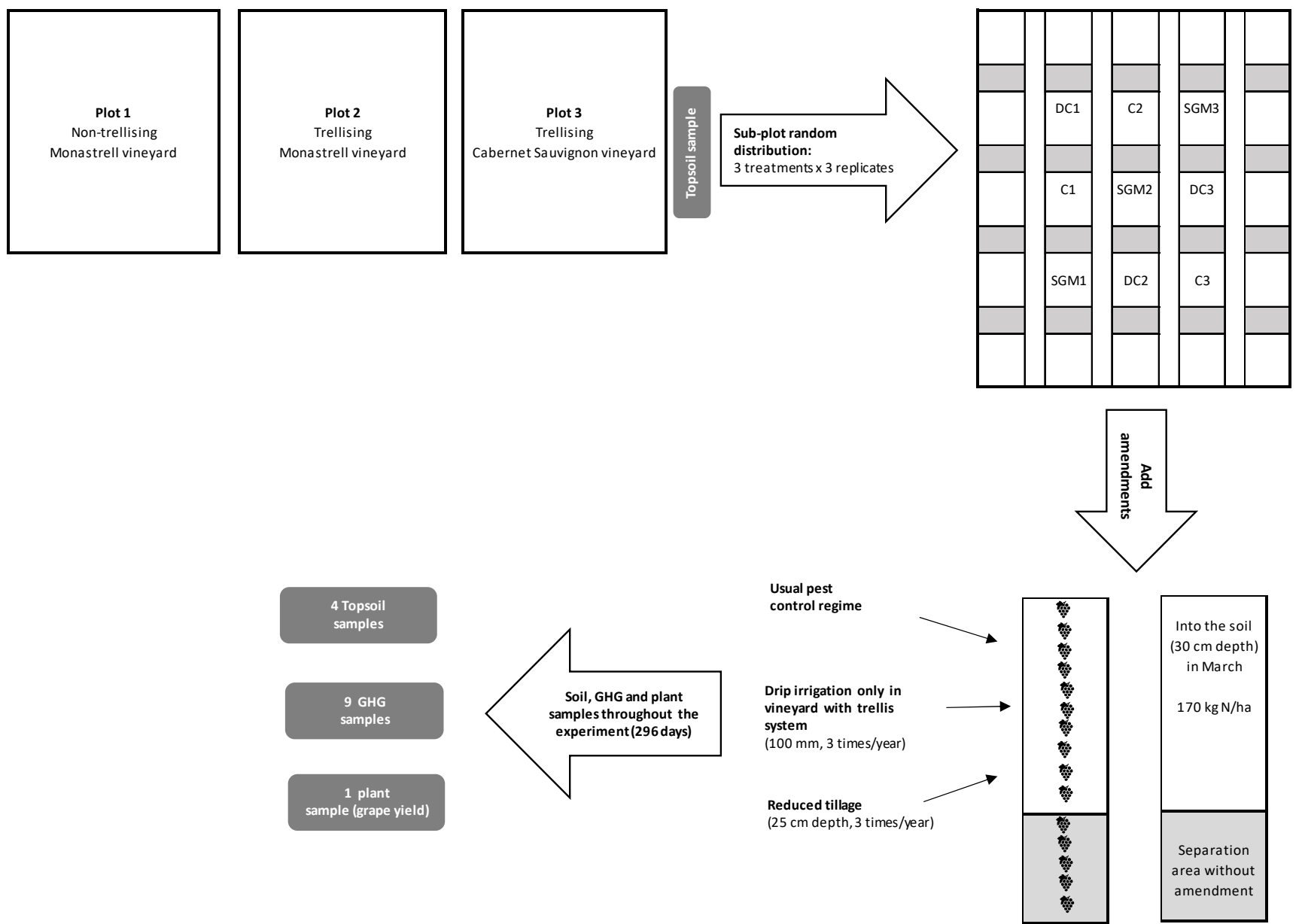

Figure 2. Scheme of the experimental design. (SGM: sheep/goat manure, DC: distillery organic waste compost, C: unfertilised control and GHG: greenhouse gas). 


\subsection{Soil Analysis and Grape Yield Determination}

In all sub-plots of each plot, topsoil samples were collected $(0-30 \mathrm{~cm}$ depth) to evaluate the effects of the studied treatments on soil physico-chemical and chemical properties. In all replicates of each treatment, six sub-samples were taken along the row of 10 vines, three on each side; then, these sub-samples were combined to compose a single sample. Soil samples were collected 1, 85, 190 and 296 days after the amendment application (24 March, 17 June and 29 September 2014 and 13 January 2015). Each soil sample was air-dried and sieved to $2 \mathrm{~mm}$, after removal of vegetation and stones.

The $\mathrm{pH}, \mathrm{EC}$, texture, active $\mathrm{CaCO}_{3}$, oxidisable $\mathrm{OC}$ and distinct forms of $\mathrm{N}$ (total Kjeldahl, nitrate and ammonium $\mathrm{N}$ ) were determined in soil samples according to the methods used by Medina et al. [29]. The characteristics and composition of the organic materials used in this experiment were determined according to Idrovo-Novillo et al. [30]. All analyses of the organic amendment and soil samples were made in triplicate.

On the days of harvest, 10 and 15 October 2014, all grape clusters of each plant contained in each sub-plot (10 vines) were weighed to determine the yield per vine, on a fresh weight basis.

\subsection{GHG Determinations}

Opaque static chambers with a volume of $18.3 \mathrm{~L}$ (diameter $36 \mathrm{~cm}$, height $18 \mathrm{~cm}$ ), and with a design similar to that described in Recio et al. [31], were used to sample the GHG fluxes. There were two chambers in each sub-plot (10 vines), adjusted to a metallic frame placed in the soil prior to the gas measurements to avoid the effect of soil disturbances on GHG fluxes. A rubber stopper with a 3-way stopcock was placed in the top of each chamber so that gas samples could be taken. Gas samples were taken 0,20, 40 and 60 min after chamber closure, by the gas pooling technique [32]. An additional syringe was connected and was pumped several times before sampling the gas fluxes, to achieve homogenous mixing of the headspace air. A 30-mL gas sample was collected from each of the two chambers in each sub-plot, with the same syringe, at each sampling time. Each combined 60-mL sample was then immediately transferred to a $20-\mathrm{mL}$ gas chromatography vial sealed with a gas-tight neoprene septum; $40 \mathrm{~mL}$ were injected with recirculation to flush the vial and overpressure was reached with the remaining $20 \mathrm{~mL}$. To minimise the effects of diurnal variation on the composition of the samples, they were taken at the same time of day (9 a.m. to 12 a.m.) in each sampling.

The GHG concentrations in the gas samples were determined by gas chromatography, according to Abalos et al. [33]. The standard curve for each gas was built using three gas standards (high, with $1500 \pm 7.50 \mathrm{ppm} \mathrm{CO}_{2}, 10 \pm 0.25 \mathrm{ppm} \mathrm{CH}_{4}$ and $2 \pm 0.05 \mathrm{ppm} \mathrm{N}_{2} \mathrm{O}$; medium, with $600 \pm 5.50 \mathrm{ppm} \mathrm{CO}_{2}, 5 \pm 0.15 \mathrm{ppm} \mathrm{CH}_{4}$ and $1.5 \pm 0.03 \mathrm{ppm} \mathrm{N}_{2} \mathrm{O}$; and low, with $200 \pm 1.00 \mathrm{ppm} \mathrm{CO}_{2}, 2 \pm 0.10 \mathrm{ppm} \mathrm{CH}_{4}$ and $200 \pm 6.00 \mathrm{ppb} \mathrm{N}_{2} \mathrm{O}$ ).

The change in gas concentration within the chamber during the $60 \mathrm{~min}$ of closure was used to calculate the flux rates of $\mathrm{N}_{2} \mathrm{O}, \mathrm{CH}_{4}$ and $\mathrm{CO}_{2}$. The linearity of gas diffusion into the chamber headspace during this closure period was determined previously, and each flux was calculated from a single determination at the end of the closure, transforming the gas measurement from $\mathrm{N}_{2} \mathrm{O}, \mathrm{CH}_{4}$ and $\mathrm{CO}_{2} \mathrm{ppm}(\mu \mathrm{L} / \mathrm{L})$ to $\mathrm{mg} \mathrm{N} \mathrm{N}_{2} \mathrm{O}-\mathrm{N}, \mathrm{CH}_{4}-\mathrm{C}$ and $\mathrm{CO}_{2}-\mathrm{C} \mathrm{m}^{-2} \mathrm{~d}^{-1}$, respectively. For this calculation, the volume of the chamber $(18.3 \mathrm{~L})$ and the surface area of the soil $\left(0.108 \mathrm{~m}^{2}\right)$ were considered [34]. Measurements of GHGs $\left(\mathrm{CO}_{2}\right.$, $\mathrm{N}_{2} \mathrm{O}$ and $\mathrm{CH}_{4}$ ) were made during the experimental period (days 1, 7, 15, 42, 85, 106, 190, 242 and 296 after the amendment application, corresponding to 24 and 31 March, 8 April, 5 May, 17 June, 7 July, 29 September and 20 November 2014 and 13 January 2015). The cumulative gas emissions during the experimental period were calculated by multiplying the average flux of two successive determinations by the length of time between them; this amount was added to the previous cumulative total [35]. 


\subsection{Statistical Methods}

SPSS v. 22.0 statistical software was used to carry out the statistical analysis. The standard deviation was determined for the mean values of each parameter measured in the soil. Statistical comparisons of the treatment means for the grape production and cumulative gas emissions were performed using one-way ANOVA and the separation of these means was established by the Tukey-b test. Finally, a factorial analysis (FA) was used to determine the correlations among the mean values of all the parameters measured in the soil. An FA shows the correlated variables as a new set of uncorrelated, mutually orthogonal variables, each of which is a linear combination of the original variables. The new, calculated variables are called 'factorial components' (FCs). The FA was performed using the mean values of the three plots for each treatment. These mean values were calculated from the data of the different days on which the soil parameters and GHG emissions were determined (24 March, 17 June and 29 September 2014 and 13 January 2015). The factorial loads of the data were analysed after the application of the Varimax normalised rotation to the coordinate system of the FCs.

\section{Results}

\subsection{Effect of the Organic Fertiliser Type on Soil Parameters and Grape Yield}

In most cases, soil pH showed an increase throughout the experiment (Figure 3A). However, this increase was, in general, lower in the amended soils than in the control soil; a lower soil $\mathrm{pH}$ could reduce vine chlorosis (common in this zone) by improving the assimilation of plant micronutrients, such as Fe. Similarly, Hannachi et al. [36] found that the addition of organic amendments produced a decrease in the $\mathrm{pH}$ of alkaline cultivated soils in semi-arid areas of southern Tunisia, considering this result as beneficial with regard to increasing the availability of nutrients to plants. These authors indicated that the oxidation of $\mathrm{NH}_{4}{ }^{+}$from $\mathrm{N}$ fertilisers (to produce nitrate), the higher root uptake of cations with respect to anions and the acidification processes of the rhizosphere may have caused the decrease in soil $\mathrm{pH}$. In our experiment, the nitrate formation was, in general, higher after the application of organic amendments. Therefore, this process could also have favoured the lowering of $\mathrm{pH}$ in comparison to the control soil. At the end of the experiment, no significant differences in soil $\mathrm{pH}$ were found among the treatments used. This result was also observed by other authors following the application of organic amendments to calcareous vineyard soils. They attributed this to the intrinsic buffer effect of this soil type $[12,21,22]$.

After the addition of SGM or DC, a significant increase in the oxidisable OC was observed in these soils, with a subsequent stabilisation throughout the experiment (Figure 3B). This initial increase was higher in the DC-treated soils, in accordance with the higher total OC content of this composted material (Table 1). During the first three months of the experiment, the oxidisable OC content was significantly reduced in most of the amended soils, especially in the case of soils with DC, probably due to organic matter mineralization. Although the organic matter of the wastes undergoes stabilisation during composting, a stable compost can contain a significant proportion of readily available organic compounds, such as microbially-derived hydrolysable sugars [37]. In the amended soils, the content of oxidisable OC was higher in the plots with trellised vines than in the plots with bush vines. This could be due to the OM present in vine root exudates, formed mostly by soluble organic compounds produced during the vegetative development of the plant. Stockmann et al. [38] indicated that root inputs to soil can represent $5 \%-33 \%$ of daily photoassimilate production. This result agrees with the higher grape production in the plots of trellised vines (Figure 5) and with the possible greater root distribution in the upper soil horizons due to the drip irrigation used in this vine-training system. At the end of the experiment, all the amended soils of the plots where the variety Monastrell was grown as bush vines had oxidisable OC contents similar to those of the control soils. However, in the plots with trellised vines, the final oxidisable OC contents of the soils with the organic amendments were $2-3$ times higher than those of the control soil. This result is of interest 
as the SOM content in the vineyards of this area is very low $(<1.5 \%)$ [39]. Increases in $\mathrm{SOM}$ due to the addition of compost or animal manure have also been reported by other authors $[12,13,21,22]$.

A

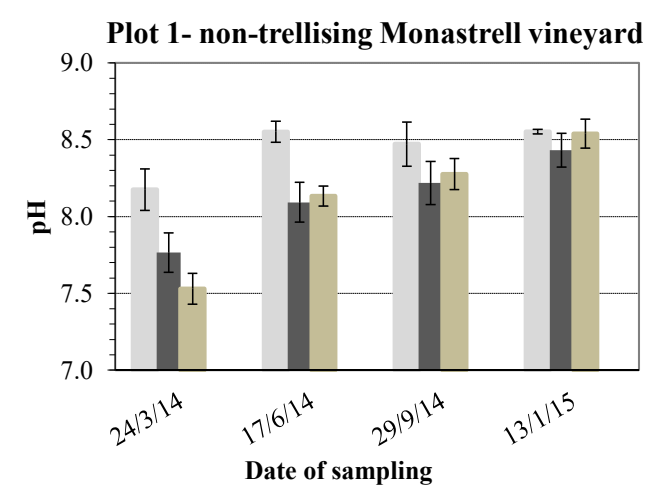

Plot 2- trellising Monastrell vineyard

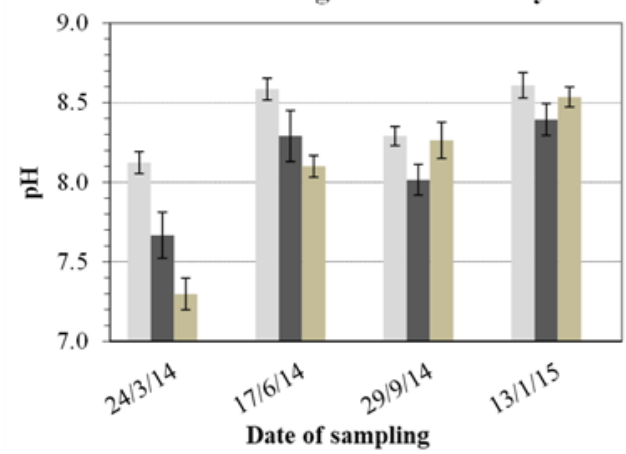

Plot 3- trellising Cabernet Sauvignon vineyard

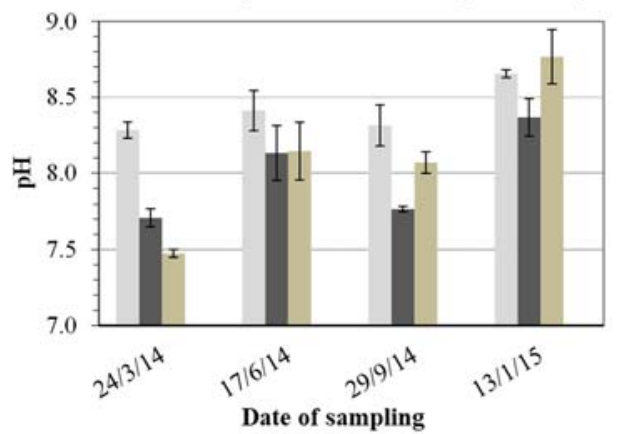

B

Plot 1- non-trellising Monastrell vineyard

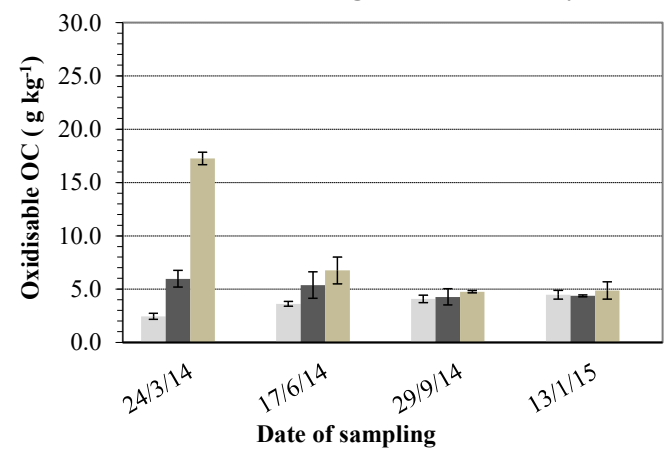

Plot 2- trellising Monastrell vineyard

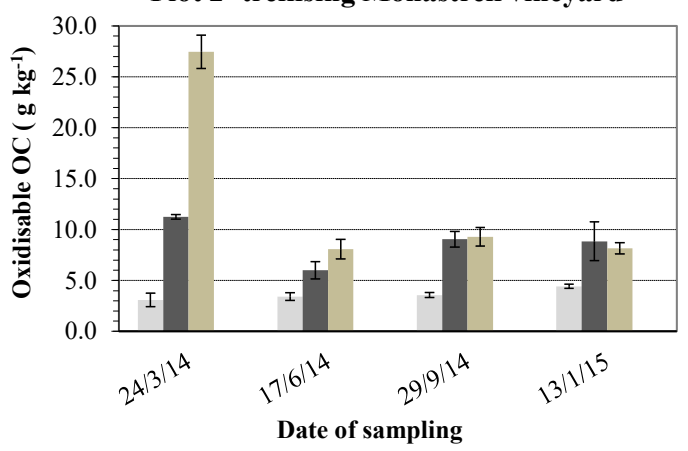

Plot 3- trellising Cabernet Sauvignon vineyard

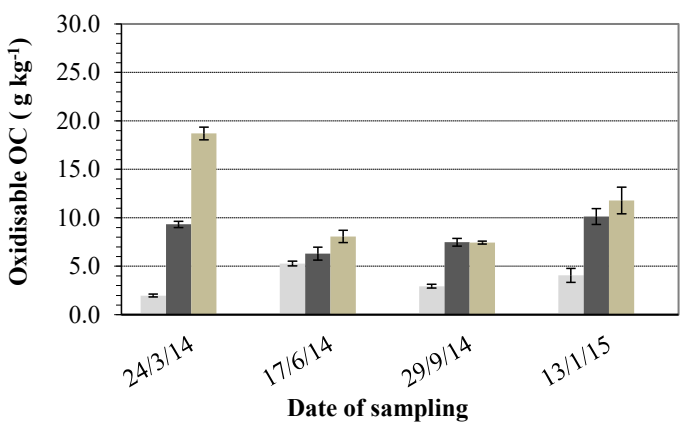

Figure 3. Changes over time in the $\mathrm{pH}(\mathbf{A})$ and oxidisable organic carbon (oxidisable OC) content (B). Error bars represent the standard error of the mean. (C: control, SGM: sheep/goat manure and DC: distillery organic waste compost).

Regarding the evolution of the soil organic $\mathrm{N}$ content, in all plots, the application of SGM or DC to the soil produced an initial increase, with respect to the control soil (Figure 4A). In general, the amended soils had organic $\mathrm{N}$ contents higher than those of the control soil throughout the experiment, especially in the case of the plots with trellised vines. In the plots with non-trellised Monastrell and trellised Cabernet Sauvignon vines, the two organic amendments produced a similar increase in the final concentration of this nutrient with respect to the control, whereas the final organic $\mathrm{N}$ level was significantly higher for the DC treatment in the Monastrell vineyard with trellising. Other authors also observed an increase in the organic $\mathrm{N}$ fraction with the addition of organic amendments to the soil in vineyards $[12,13,21-23]$. 
A

Plot 1- non-trellising Monastrell vineyard

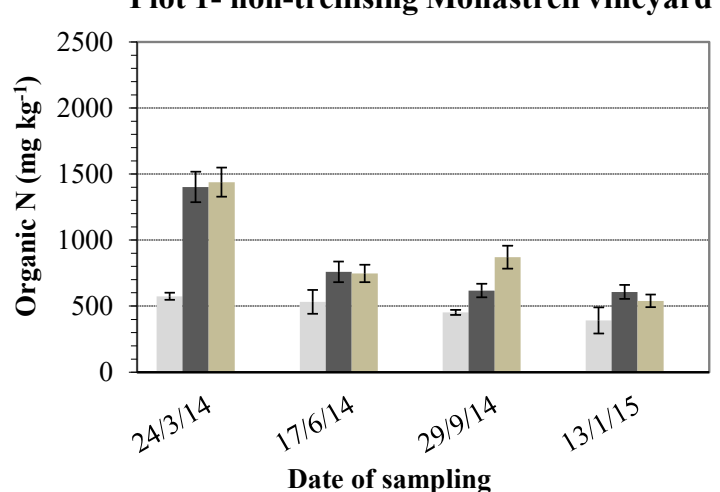

Plot 2- trellising Monastrell vineyard

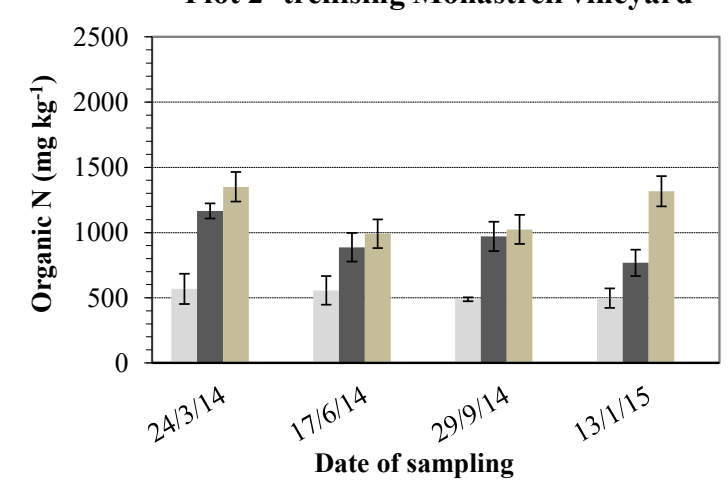

B

Plot 1- non-trellising Monastrell vineyard

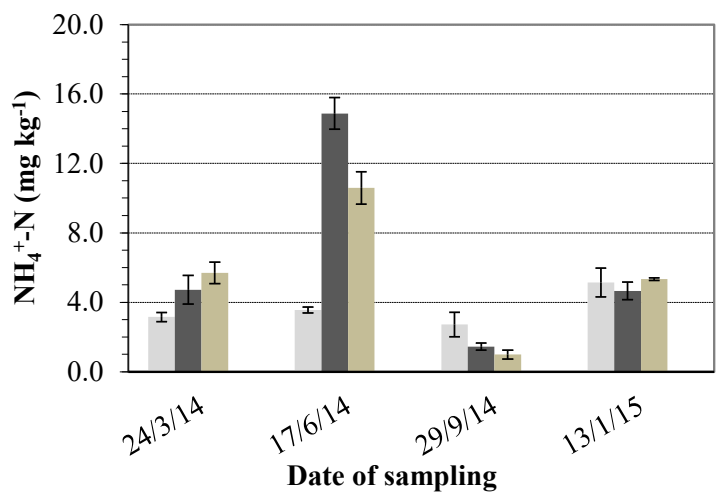

Plot 2- trellising Monastrell vineyard

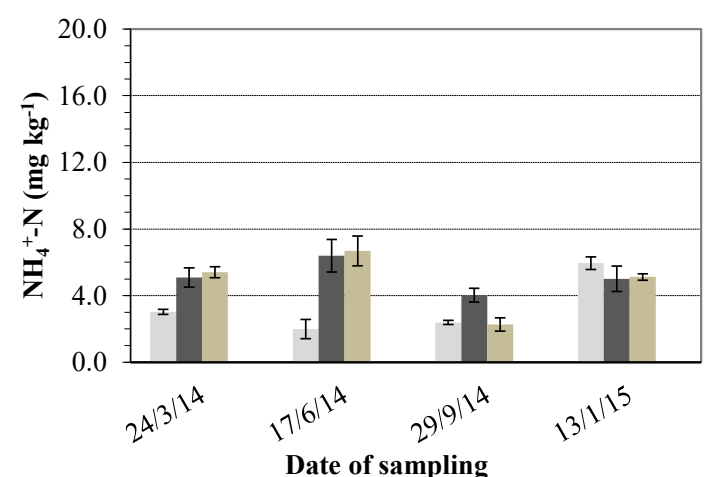

Figure 4. Cont.
Plot 1- non-trellising Monastrell vineyard

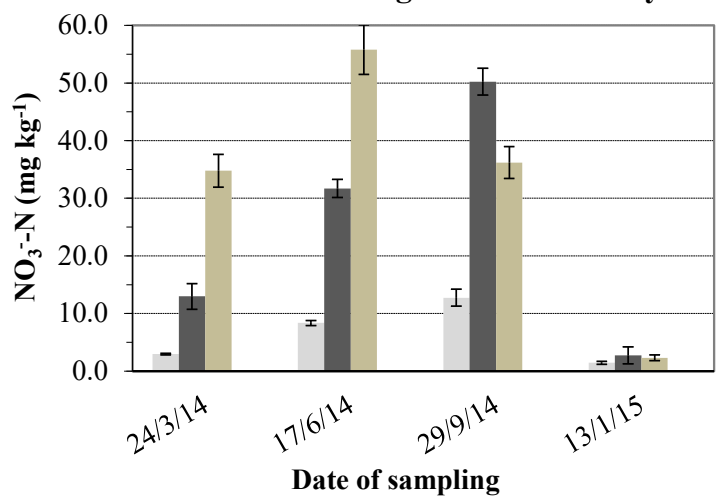

Plot 2- trellising Monastrell vineyard

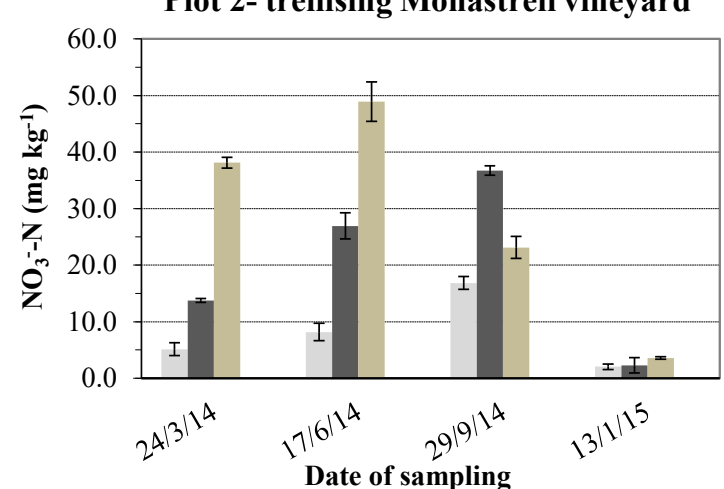


Plot 3- trellising Cabernet Sauvignon vineyard

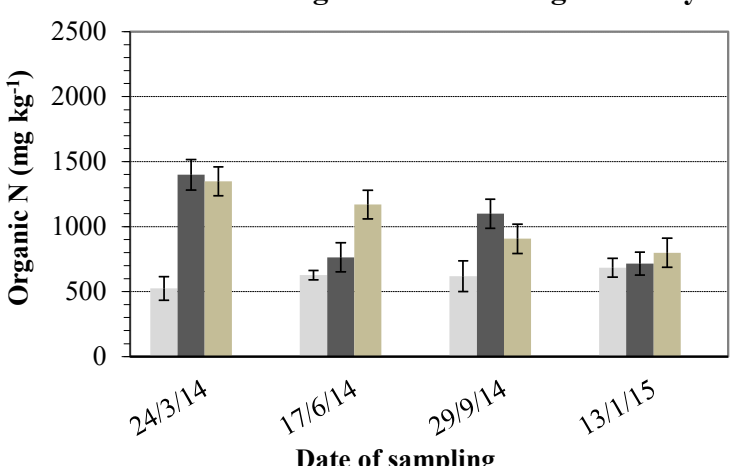

Plot 3- trellising Cabernet Sauvignon vineyard

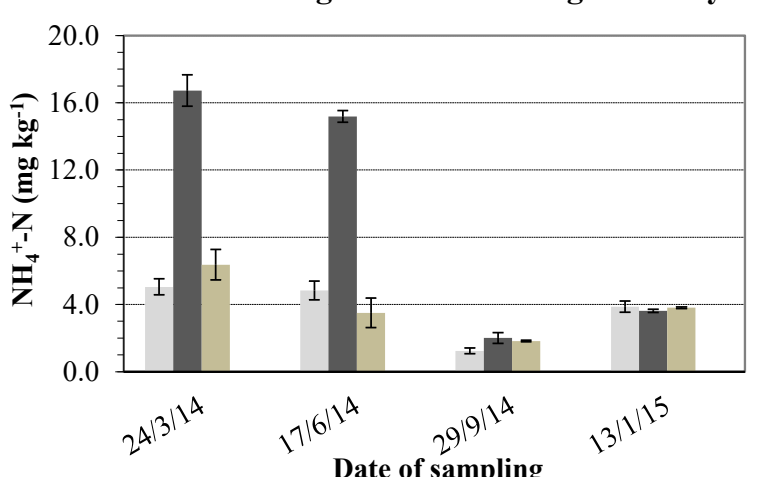

Plot 3- trellising Cabernet Sauvignon vineyard

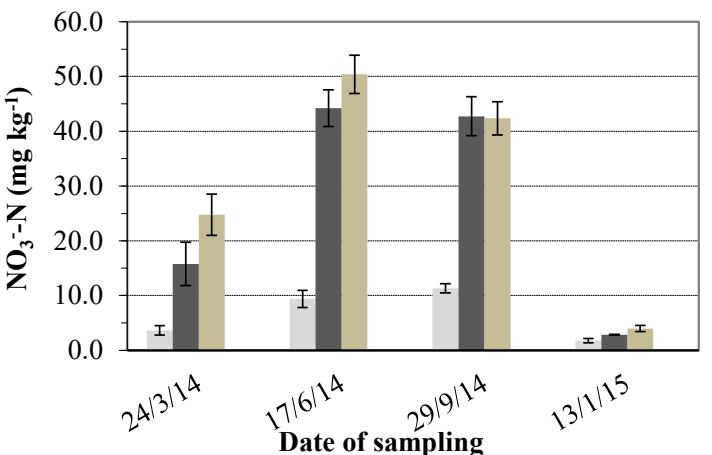

\section{$=\mathrm{C} \quad \mathrm{SGM}=\mathrm{DC}$}

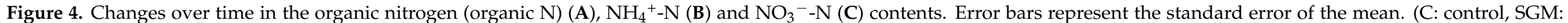
sheep/goat manure and DC: distillery organic waste compost). 
The evolution of the $\mathrm{NH}_{4}{ }^{+}-\mathrm{N}$ concentration was similar in all plots (Figure 4B). The initial values were significantly higher in the amended soils. Later, in most soils, the $\mathrm{NH}_{4}{ }^{+}-\mathrm{N}$ levels had increased on 17 June 2014 and 13 January 2015, when the increase in temperature (in summer) had begun and after the autumn rains, respectively (Figure 1). Morlat and Chaussod [12] and Bustamante et al. [21] also reported that the $\mathrm{N}$ mineralisation in vineyard soils can be positively affected by rainfall and temperature. Moreover, the soil tillage carried out before the soil sampling on 13 January 2015 could have contributed to the increased $\mathrm{NH}_{4}{ }^{+}-\mathrm{N}$ content (Figures 1 and 4B), as Steenwerth and Belina [40] also observed in a Mediterranean vineyard agroecosystem with conventional tillage. At the end of the experiment, no great differences in the final values of this parameter were found among the treatments. The $\mathrm{NH}_{4}{ }^{+}-\mathrm{N}$ contents were highest in the SGM soils, probably due to the lower degree of stabilisation of this organic amendment, favouring the mineralisation of organic $\mathrm{N}$ [21]. It is also noteworthy that in all plots the $\mathrm{NH}_{4}{ }^{+}-\mathrm{N}$ content was low $(0.8-16.7 \mathrm{mg}$ $\mathrm{NH}_{4}{ }^{+}-\mathrm{N} \mathrm{kg}^{-1}$ soil), which is usual in Mediterranean areas where the mineralisation and nitrification rates are high [41]. Therefore, the pool of soluble mineral $\mathrm{N}$ in vineyards is dominated by $\mathrm{NO}_{3}{ }^{-}-\mathrm{N}$ during most of the growing season, as observed in this experiment (Figure 4C) and by Christou et al. [42] in a study on the $\mathrm{N}$ dynamic in a Mediterranean vineyard soil amended with poultry manure compost.

In all plots, the nitrate contents were higher in the amended soils than in the control soil (Figure 4C). This behaviour persisted, in general, throughout the experiment, except at the end when no significant differences due to the treatment were found in the $\mathrm{NO}_{3}{ }^{-}-\mathrm{N}$ concentration. Moreover, in all soils, there was a significant reduction in the $\mathrm{NO}_{3}{ }^{-}-\mathrm{N}$ content at the end of the experiment. This could be due mainly to the leaching of nitrate into deeper layers after the autumn rains (Figure 1).

Figure 5 shows the grape yield (kg per vine) for each treatment in the three studied plots. In all plots, it was higher in the treatments with organic amendments than in the control. It is also noteworthy that the yield was higher in the plots with trellised vines, especially in the case of Cabernet Sauvignon, than in the plot with bush vines. This could be due to the rain-fed conditions of the plot with non-trellised vines, which-unlike the plots with trellised vines-did not have drip irrigation. Romero et al. [43] also observed that severe water stress in the vine decreases its fine root development, water uptake and grape production per plant.

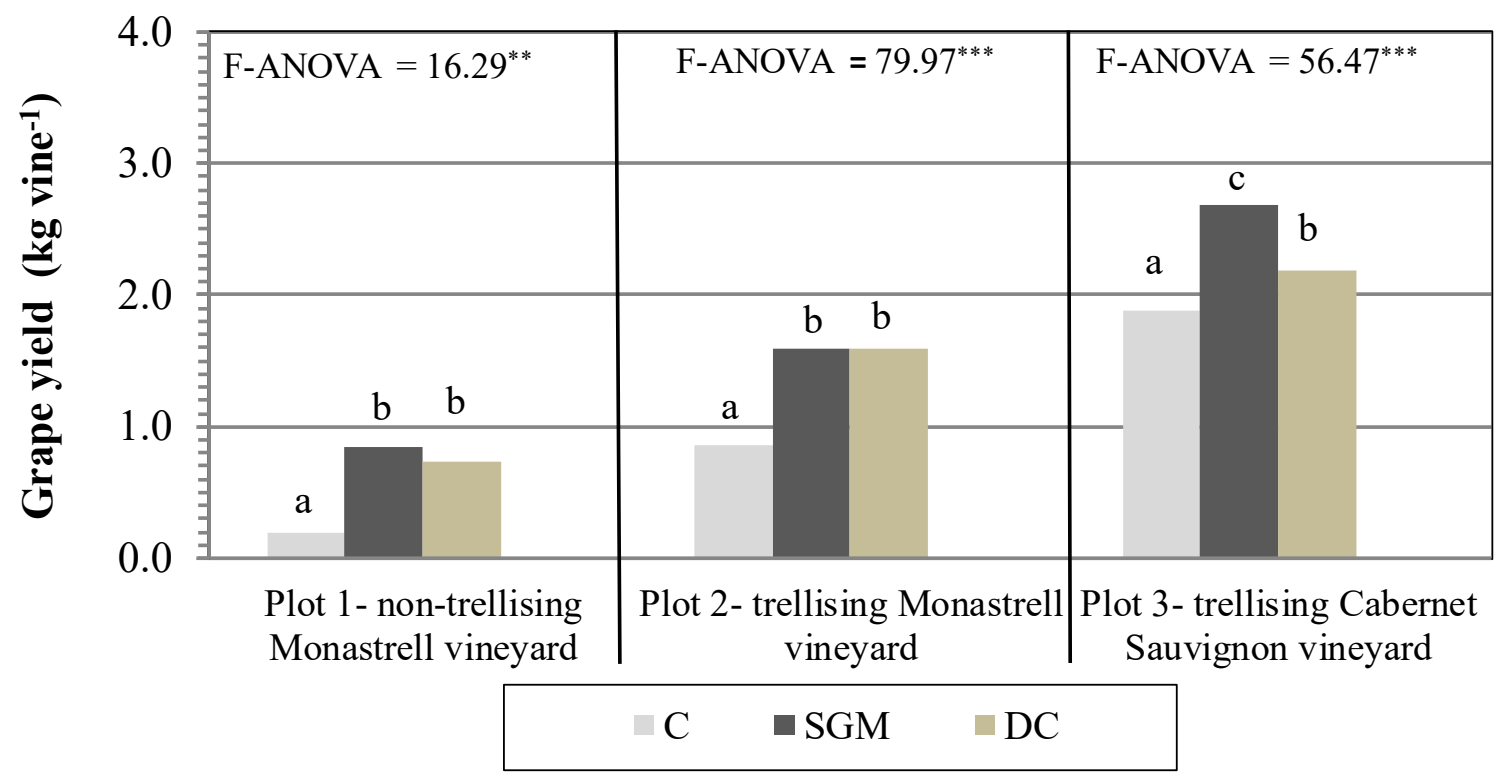

Figure 5. Grape yield per vine. In each plot, bars with the same letter are not significantly different at $p<0.05$ (Tukey-b test). ${ }^{* *}$ and ${ }^{* * *}$ : significant at $p<0.01$ and 0.001 , respectively. (C: control, SGM: sheep/goat manure and DC: distillery organic waste compost). 


\subsection{Effect of the Organic Fertiliser Type on Greenhouse Gas Emissions}

In all plots, the $\mathrm{N}_{2} \mathrm{O}$ flux peaked 7-15 days after the start of the experiment (Figure 6A). In the control (where organic amendment was not applied), this could be due to the increase in temperature registered at the beginning of the experiment. Some authors have found a positive correlation among temperature, microbial activity and $\mathrm{N}_{2} \mathrm{O}$ fluxes $[44,45]$. In addition to the impact of an increase in temperature, in the amended soils, this initial growth in $\mathrm{N}_{2} \mathrm{O}$ emissions could be associated with an enhanced availability of labile, $\mathrm{C}$ enriched substrates derived from the added organic matter. These substrates are degraded by soil microorganisms, reducing temporarily the soil $\mathrm{O}_{2}$ supply and, therefore, promoting anaerobic microsites that are more suitable for denitrification processes and thus hot-spots for the production of $\mathrm{N}_{2} \mathrm{O}$ [46]. Subsequently, the $\mathrm{N}_{2} \mathrm{O}$ flux declined, reaching its lowest values during the dry summer period in most cases, especially in the plots with trellised vines. Beare et al. [47] also observed that the production of $\mathrm{N}_{2} \mathrm{O}$ was strongly reduced during drier periods of the crop season, because of the lower soil microbiological activity. After this dry period, a pulse in the $\mathrm{N}_{2} \mathrm{O}$ flux was observed, probably due to the recovery of the activity of soil microorganisms because of the soil rewetting associated with the September and November rainfall (Figure 1). This increase in the soil biological activity is produced generally by the availability of $\mathrm{C}$ and $\mathrm{N}$ substrates accumulated in the soil during dry periods, when the soil microorganisms have died [14]. Despite the autumn rains, the soil moisture was not high enough to promote, in combination with the available $C$ and $\mathrm{N}$ substrates, highly denitrifying conditions in soil micropores. Therefore, the aerobic oxidation of $\mathrm{NH}_{4}{ }^{+}$through nitrification would have been the main process behind the production of $\mathrm{N}_{2} \mathrm{O}$ measured at this stage of the experimental period. Galbally et al. [48] found that in semi-arid conditions the low pulses of $\mathrm{N}_{2} \mathrm{O}$ emissions produced after rainfall events could come from the activity of nitrifying aerobic bacteria. After the soil wetting cycle, the $\mathrm{N}_{2} \mathrm{O}$ emissions diminished until the end of the experiment. It is also noteworthy that the emissions of $\mathrm{N}_{2} \mathrm{O}$ were greater in the plot with bush vines (plot 1) than in plots 2 and 3 with trellised vines, probably due to the synergistic effect of reduced plant growth and lower $\mathrm{N}$ use efficiency in the former [49]. This is supported by the lower grape production per plant found in plot 1 (Figure 5). However, the $\mathrm{N}_{2} \mathrm{O}$ emissions in all plots during the studied growing season were very low compared to those found by CallejaCervantes et al. [13] in a vine system with a Mediterranean climate, during a period of 115 days after the addition of different composted materials. These authors found that the soils receiving the organic amendments had maximum $\mathrm{N}_{2} \mathrm{O}$ fluxes between 0.4 and $1.4 \mathrm{mg}$ $\mathrm{N}_{2} \mathrm{O}-\mathrm{N} \mathrm{m}^{-2} \mathrm{~d}^{-1}$.

In the case of the $\mathrm{CH}_{4}$ emissions of the soil, negative $\mathrm{CH}_{4}$ fluxes were recorded in all plots during most of the experiment (Figure 6B). Shvaleva et al. [16] also observed that Mediterranean dry ecosystems can represent a significant sink for atmospheric $\mathrm{CH}_{4}$. The low water content of these soils could increase the rate of oxidation of this greenhouse gas, probably due to the higher content of oxygen in the soil porous spaces, which also allows for greater diffusion of $\mathrm{CH}_{4}$ down the soil profile [50]. The diffusion of $\mathrm{CH}_{4}$ and $\mathrm{O}_{2}$, the main substrates for the activity of methanotrophic bacteria, was also favoured by the coarse texture of our soils [51]. In addition, the mineral $\mathrm{N}$ concentration of the studied soils was compatible with the growth of methanotrophic bacteria, since high nitrification rates can produce toxic levels of $\mathrm{N}_{2} \mathrm{O}$ and $\mathrm{NH}_{2} \mathrm{OH}$ that affect $\mathrm{CH}_{4}$-consuming bacteria [52]. Moreover, high $\mathrm{NH}_{4}{ }^{+}$contents in the soil can reduce $\mathrm{CH}_{4}$ oxidation, due to the methanotrophic oxidation of $\mathrm{NH}_{4}{ }^{+}$being greater than that of $\mathrm{CH}_{4}$ [52]. Therefore, the low inorganic $\mathrm{N}$ content of these soils was probably the main determinant of their function as $\mathrm{CH}_{4}$ sinks. 
A

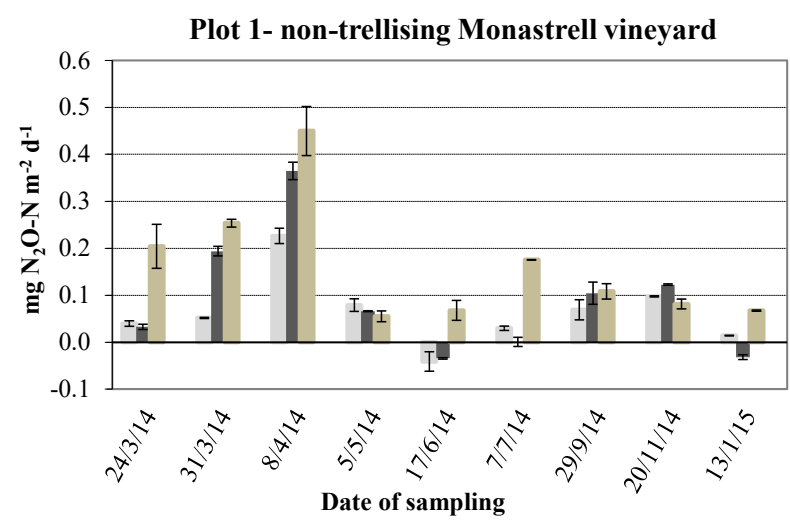

Plot 2- trellising Monastrell vineyard

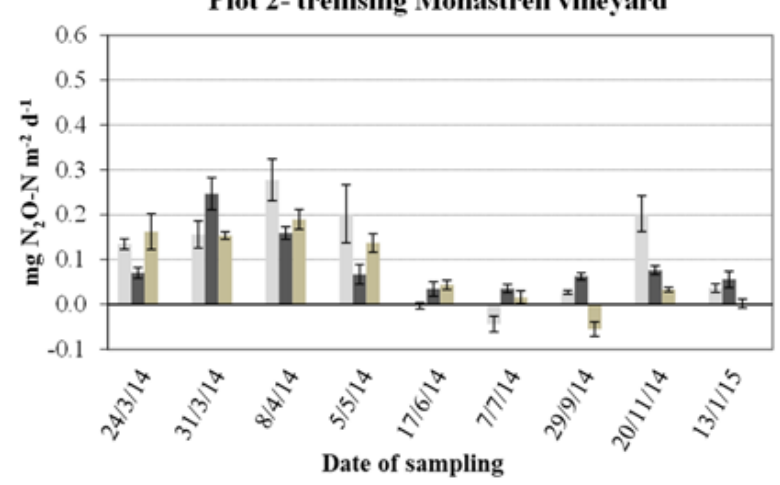

B

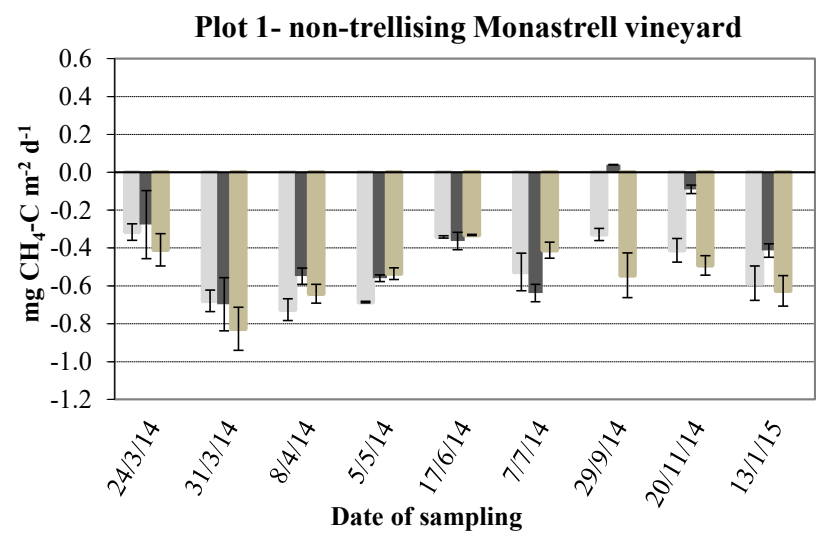

Plot 2- trellising Monastrell vineyard

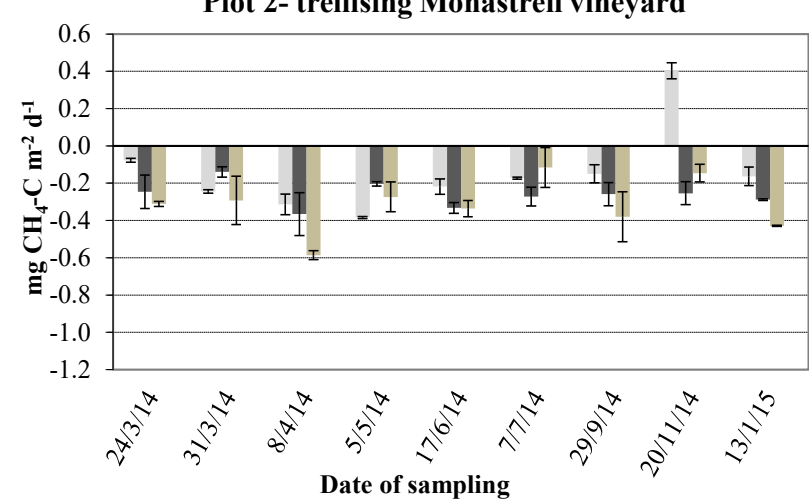

Figure 6. Cont.
C
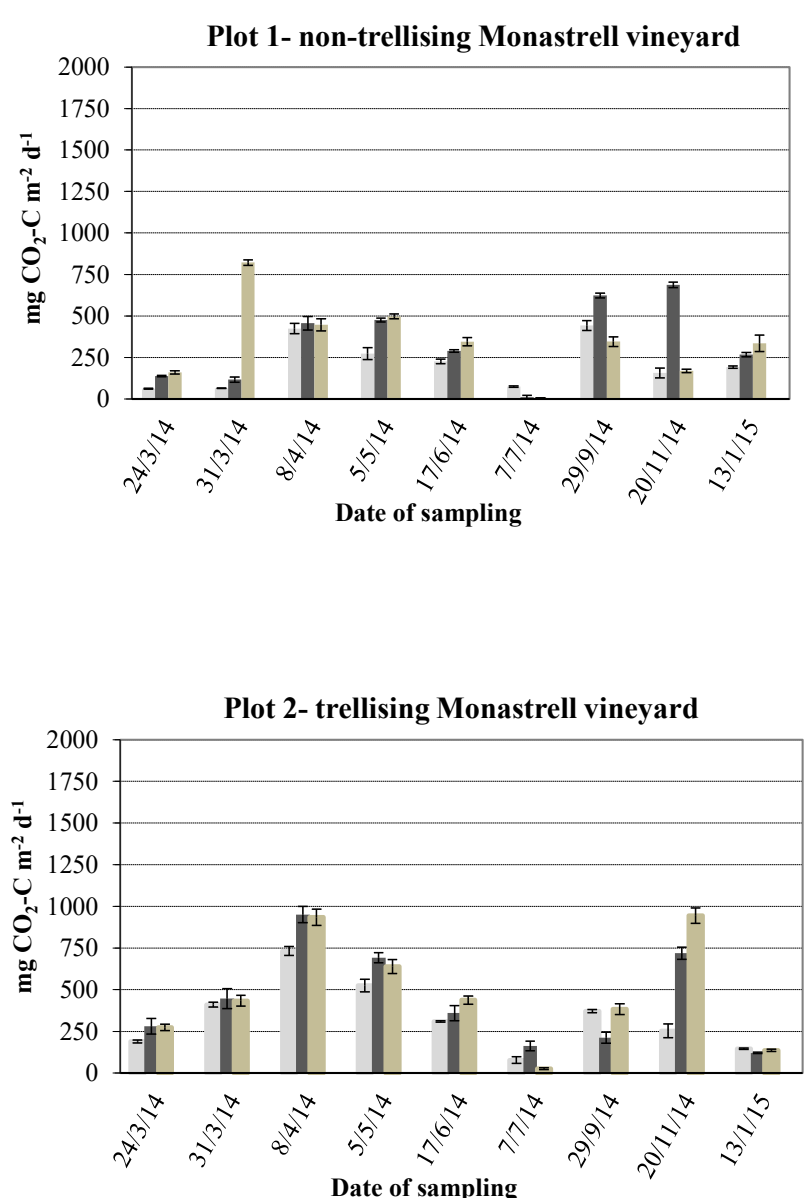


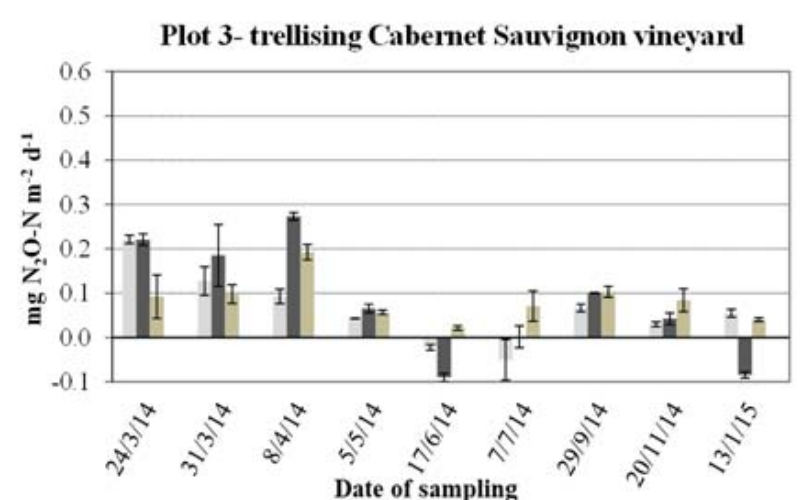

Plot 3- trellising Cabernet Sauvignon vineyard

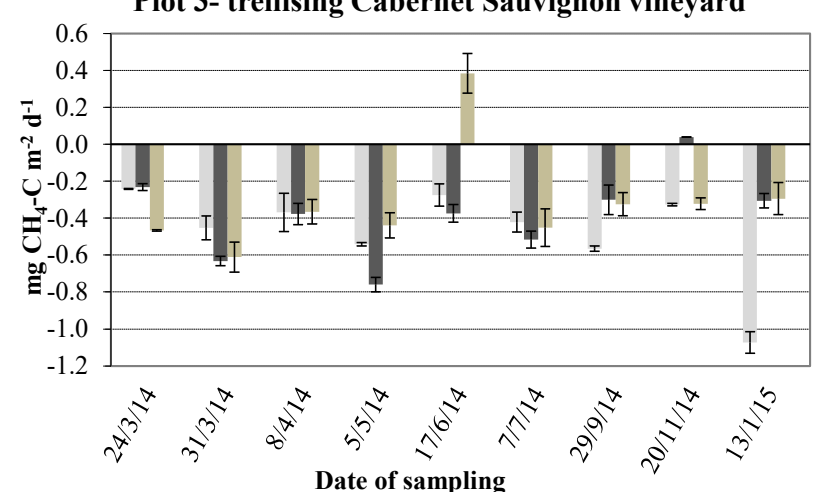

Date of sampling
Plot 3- trellising Cabernet Sauvignon vineyard

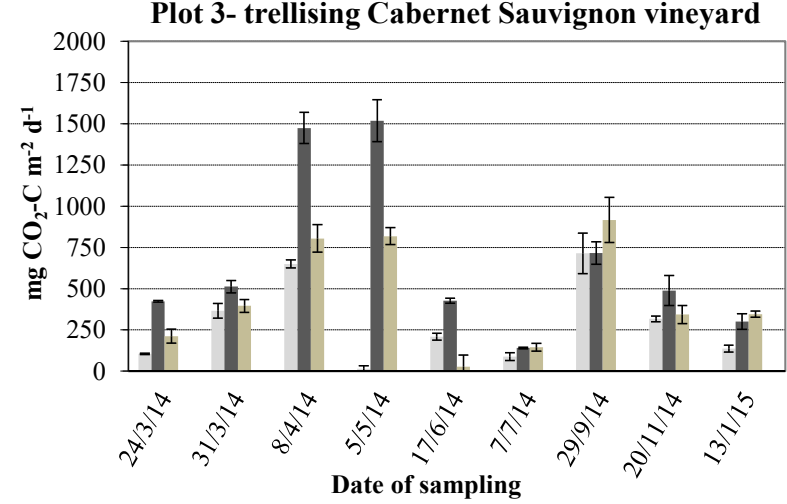

\section{$=\mathrm{C} \quad \mathrm{SGM}=\mathrm{DC}$}

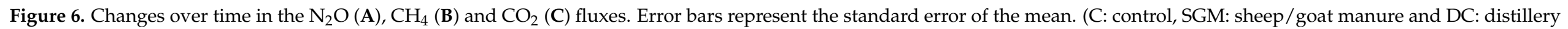
organic waste compost). 
With regard to soil respiration, the $\mathrm{CO}_{2}$ flux emitted from the soil varied enormously throughout the experimental period, in all plots (Figure 6C). The range of values of these fluxes was 7-1518 $\mathrm{mg} \mathrm{C}-\mathrm{CO}_{2} \mathrm{~m}^{-2} \mathrm{~d}^{-1}$, the highest values being recorded in the amended soils. In general, the emission of this greenhouse gas was highest during the first 42 days of the experiment, possibly due to the addition of the organic amendments and to the tillage carried out in early April. An increase in $\mathrm{CO}_{2}$ emission with the addition of organic amendments is commonly attributed to an increase in the metabolic activity of the microorganisms present in the soil, due to the availability of easily degradable compounds from these amendments [53]. In this way, increases in the emission of $\mathrm{CO}_{2}$ from agricultural soils after the addition of organic amendments have been previously reported by different authors $[54,55]$. In general, in the vine systems studied here, the SGM treatment generated higher emissions of $\mathrm{CO}_{2}$ than the compost used. This may well be related to the decomposition rate of the organic amendments [54], since SGM has an OM content that is more labile and less stabilised than that of the compost. Soil tillage can also contribute to the $\mathrm{CO}_{2}$ flux emitted from the soil, possibly due to greater soil aeration and the breakdown of soil macroaggregates, which leaves previously protected labile OM prone to decomposition [17]. The $\mathrm{CO}_{2}$ emissions were lowest in the dry summer period (July and August), when the water content of the soil was low, even in the plots with trellised vines, where irrigation was carried out. Shvaleva et al. [16] also observed this reduction in $\mathrm{CO}_{2}$ emissions from the soil in the summer, even in irrigated plots, in a study of the influence of the rainfall and irrigation on the GHG emissions in oak forests in southern Portugal. It is also of note that the emissions of $\mathrm{CO}_{2}$ were greater in the plots with trellised vines, especially in the case of Cabernet Sauvignon (plot 3). This is probably related to the higher grape production of this variety (Figure 5), with greater root exudation of labile C resulting in increased $\mathrm{CO}_{2}$ emissions during the vegetative development of the plant [48]. However, the $\mathrm{CO}_{2}$ emissions in the present experiment are within the range of values observed by Lardo et al. [8] in a study of the dynamics of the total edaphic respiration over a period of three years in vineyard soils of southern Italy $\left(213-11,978 \mathrm{mg} \mathrm{C}-\mathrm{CO}_{2} \mathrm{~m}^{-2} \mathrm{~d}^{-1}\right)$.

Figure $7 \mathrm{~A}-\mathrm{C}$ shows the cumulative $\mathrm{N}_{2} \mathrm{O}, \mathrm{CH}_{4}$ and $\mathrm{CO}_{2}$ emissions, respectively, during the vine growing season, as affected by the different treatments. In plot 1 (non-trellised Monastrell vines), the DC treatment gave the highest accumulated $\mathrm{N}_{2} \mathrm{O}$ emissions at the end of the experiment (297 days), whereas no significant differences were observed in these emissions between the SGM-amended and control soils. In the plot with trellised Monastrell vines, no statistically significant differences in the cumulative $\mathrm{N}_{2} \mathrm{O}$ emissions were observed between the compost treatment and the control, the values being highest in the SGM soil (Figure 7A). In plot 3, with trellised Cabernet Sauvignon vines, the cumulative $\mathrm{N}_{2} \mathrm{O}$ emissions were lowest in the control soil and highest in the DC soil, while the SGM soil had intermediate values. The cumulative emissions of $\mathrm{N}_{2} \mathrm{O}$ were greater in the plot with bush vines (plot 1) than in those with trellised vines (plots 2 and 3 ). However, the cumulative $\mathrm{N}_{2} \mathrm{O}$ emissions, in all plots, were very low compared to those found by Aguil-

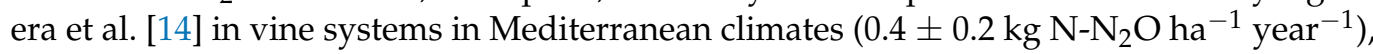
in a meta-analysis of the emissions of this greenhouse gas in different Mediterranean agroecosystems. These authors also found that among the different types of crop studied (vineyard, horticultural, cereals and legumes) the vineyards gave the lowest $\mathrm{N}_{2} \mathrm{O}$ emissions, associated with the low inputs of $\mathrm{N}$ and water of these agricultural systems.

Significant differences in the accumulated emissions of $\mathrm{CH}_{4}$ were observed among the treatments tested in the three plots of this study (Figure 7B). In the plot with non-trellised Monastrell vines, the $\mathrm{CH}_{4}$ consumption was lowest in the SGM soil, while the control and DC soils did not differ significantly in their negative emissions of $\mathrm{CH}_{4}$. However, the SGM and DC soils showed the highest capacity for $\mathrm{CH}_{4}$ oxidation, in comparison to the control soil, in plot 2 (trellised Monastrell vineyard). Moreover, in the plot with trellised Cabernet Sauvignon vines the $\mathrm{CH}_{4}$ consumption was highest in the control soil, while it was statistically similar in the DC and SGM soils. 
Regarding the accumulated soil emissions of $\mathrm{CO}_{2}$, in the plot with non-trellised Monastrell vines, no significant differences were found among the treatments tested (Figure 7C). However, in the plot with the trellised Monastrell vines, the SGM and control treatments gave the highest and lowest accumulated emissions of $\mathrm{CO}_{2}$, respectively. Furthermore, in the plot with the trellised Cabernet Sauvignon vines there were significant differences for both treatments, with respect to the control: the emission of $\mathrm{CO}_{2}$ was highest for the SGM treatment, followed by DC and then the control. In general, in the vine systems studied here, the SGM treatment generated higher cumulative emissions of $\mathrm{CO}_{2}$ than the compost used. This may well be related to the decomposition rate of the organic amendments used [54], since SGM has an OM content that is more labile and less stabilised than that of the compost.

A

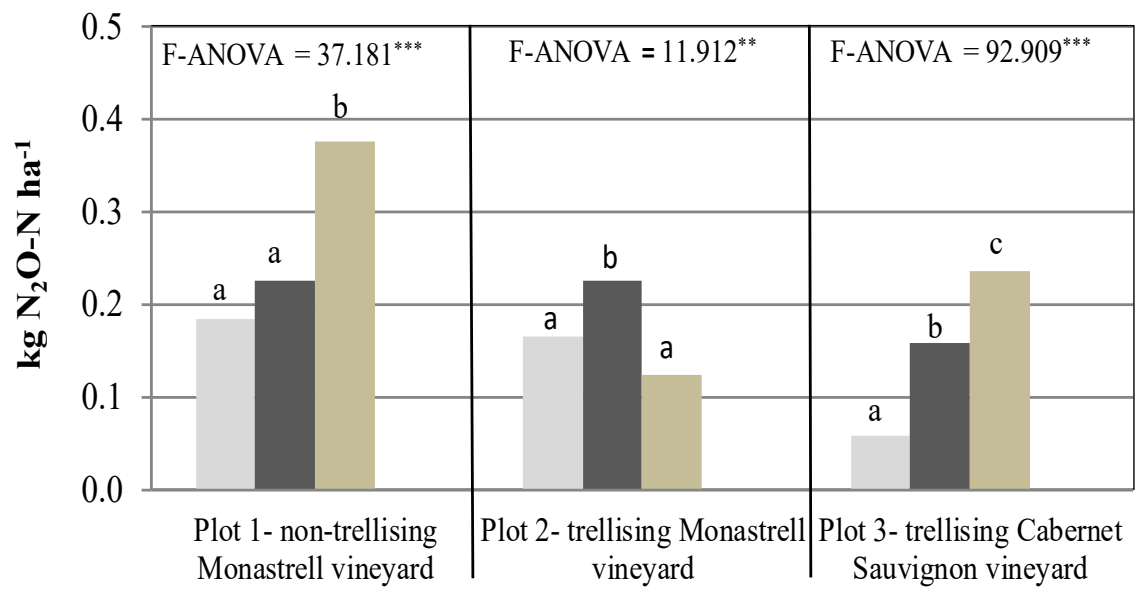

B

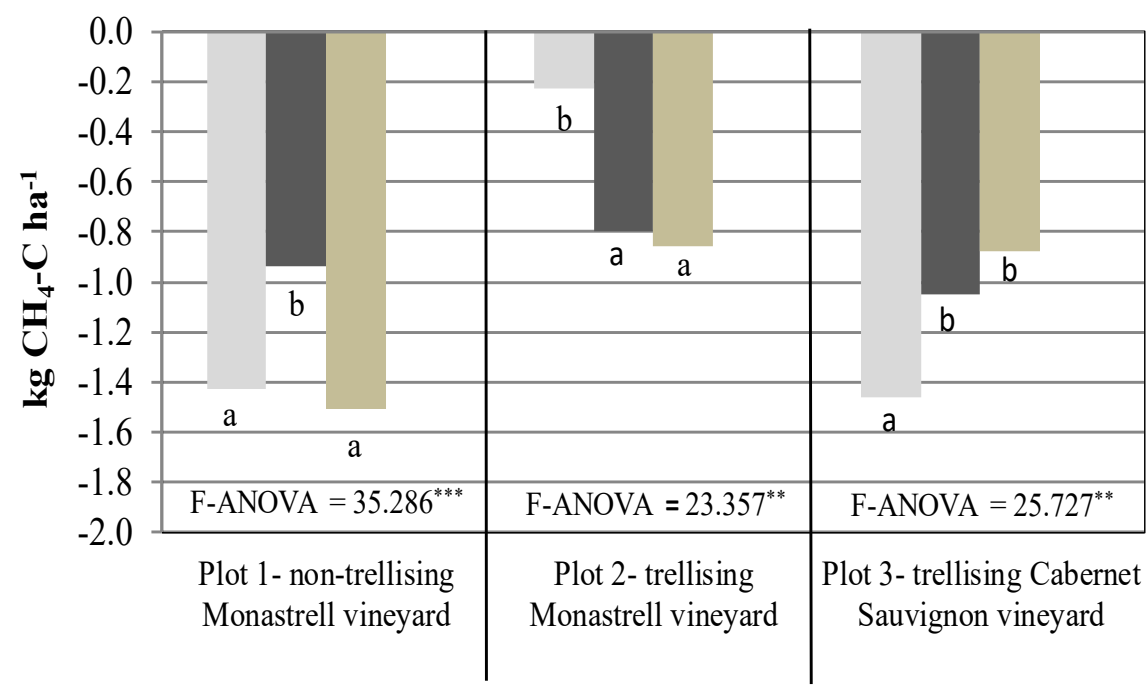

Figure 7. Cont. 

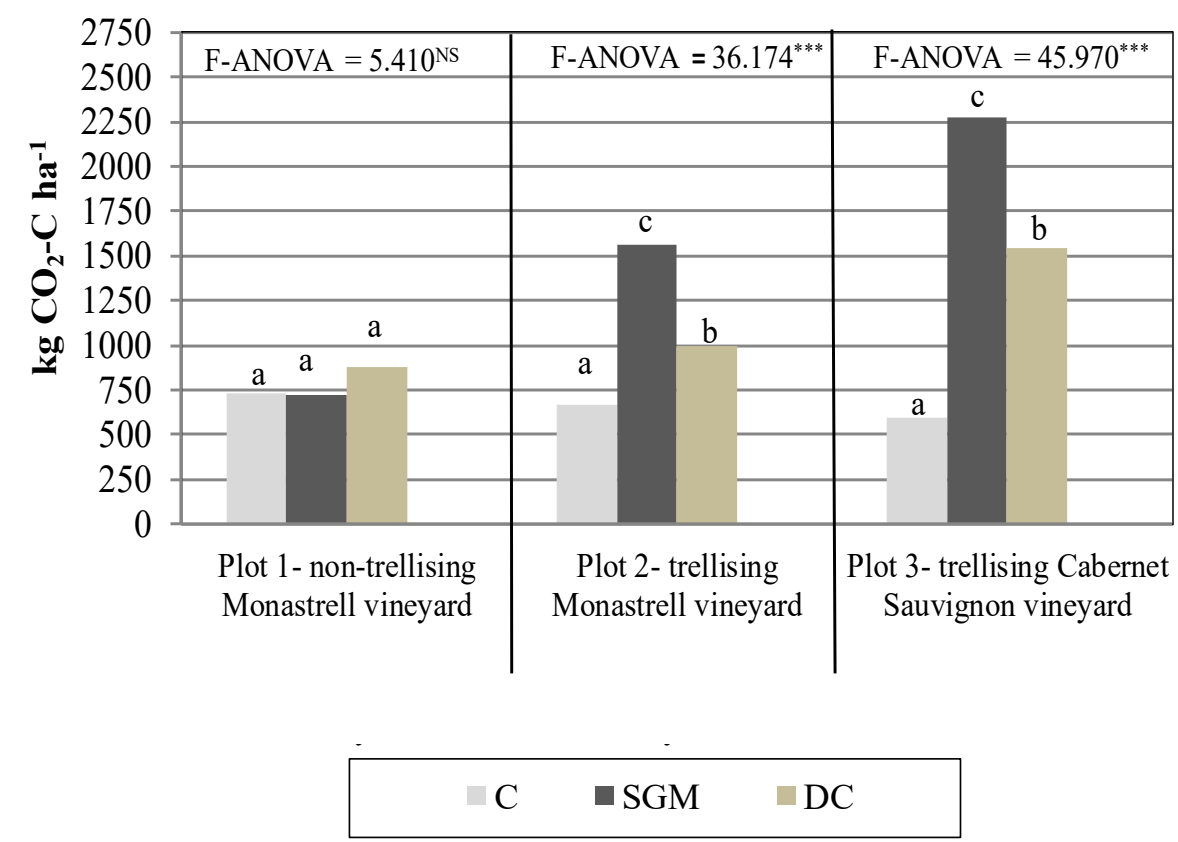

Figure 7. Cumulative $\mathrm{N}_{2} \mathrm{O}(\mathbf{A}), \mathrm{CH}_{4}(\mathbf{B})$ and $\mathrm{CO}_{2}(\mathbf{C})$ emissions. In each plot, bars with the same letter are not significantly different at $p<0.05$ (Tukey-b test). ${ }^{* *}$ and ${ }^{* *}$ : Significant at $p<0.01$ and 0.001 , respectively. ${ }^{\mathrm{NS}}$ : not significant (C: control, SGM: sheep/goat manure and DC: distillery organic waste compost).

\subsection{Multivariate Analysis}

Figure 8 shows the plot of the FCs extracted by FA, for the soil parameters and GHG emissions studied $(n=8)$. This statistical analysis had a measure of sampling adequacy (Kaiser-Meyer-Olkin) above 0.5 , the Bartlett sphericity test gave a $P$ value of 0.000 and all variables had an extraction value $>0.5$. These data indicate that the model proposed was suitable. This model grouped the studied parameters into two FCs, with a cumulative explained variance $>70 \%$ : FC1 explained $48.9 \%$ and FC2 $22.1 \%$. In FC1, the following parameters were grouped: organic $\mathrm{N}$, oxidisable OC, $\mathrm{pH}, \mathrm{N}_{2} \mathrm{O}-\mathrm{N}$ emission and $\mathrm{NH}_{4}{ }^{+}-\mathrm{N}$. All these variables were positively correlated among themselves, except $\mathrm{pH}$, indicating that the increase in soil organic $\mathrm{C}$ and $\mathrm{N}$ caused by the addition of the organic amendments contributed to the reduction of soil $\mathrm{pH}$, as was also found by Hannachi et al. [36] in alkaline cultivated soils of southern Tunisia. In addition, the $\mathrm{NH}_{4}{ }^{+}-\mathrm{N}$ content and $\mathrm{N}_{2} \mathrm{O}-\mathrm{N}$ emission were positively correlated, possibly because in this agroecosystem the nitrification processes contributed to a greater extent to the emissions of $\mathrm{N}_{2} \mathrm{O}$ than the denitrification processes. Other authors also found in their studies that $\mathrm{N}_{2} \mathrm{O}$ emissions could be explained better by the soil $\mathrm{NH}_{4}{ }^{+}$content than by the $\mathrm{NO}_{3}{ }^{-}$content, due to the nitrification processes [15,45]. In $\mathrm{FC} 2$, the following parameters were grouped and positively correlated: $\mathrm{NO}_{3}{ }^{-}-\mathrm{N}, \mathrm{CH}_{4}-\mathrm{C}$ emission and $\mathrm{CO}_{2}-\mathrm{C}$ emission. A positive correlation between $\mathrm{CO}_{2}$ and $\mathrm{CH}_{4}$ emissions was also observed by Shvaleva et al. [16] in an experiment carried out to study the influence of rainfall and irrigation on the GHG emissions in oak forests in southern Portugal. These authors stated that this correlation was due to the close relationship between the cycles of $\mathrm{C}$ and $\mathrm{N}$, which involve microorganisms that directly contribute to the fluxes of $\mathrm{CO}_{2}, \mathrm{~N}_{2} \mathrm{O}$ and $\mathrm{CH}_{4}$ in the soil. Moreover, the positive correlation between the $\mathrm{NO}_{3}{ }^{-}-\mathrm{N}$ content and $\mathrm{CH}_{4}$ emissions could be related to the inhibition of $\mathrm{CH}_{4}$ oxidation by soil microorganisms when the concentration of nitrate in the soil is high, producing higher $\mathrm{CH}_{4}$ emissions, as mentioned in the section Effect of the organic fertiliser type on greenhouse gas emissions. 


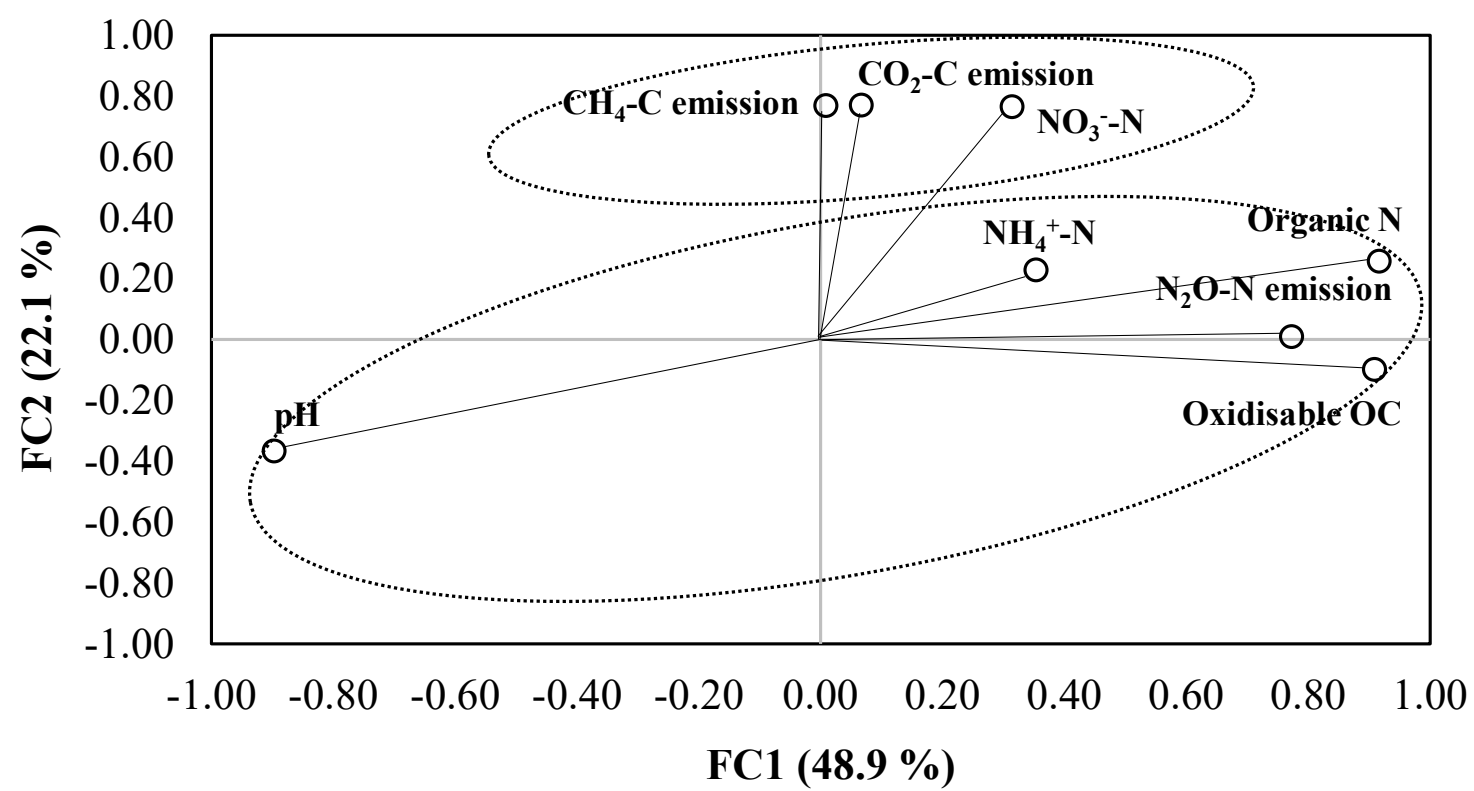

Figure 8. Plot of the first and second factorial components (FCs) extracted by factorial analysis, for the soil parameters and greenhouse gas emissions studied. The ellipses drawn based on statistical tests indicate the parameters grouped in each FC.

\section{Conclusions}

This work has evaluated the short-term effect of the organic fertiliser type on soil fertility, grape production and greenhouse gas emissions in semi-arid vineyard agroecosystems with different agricultural practices. The use of organic amendments increased the grape yield and improved the fertility of the soil, especially in the case of the drip-irrigated trellising vineyards. Regarding the environmental aspects, in general, the use of manure generated higher emissions of $\mathrm{CO}_{2}$ than the compost used. Moreover, higher grape production enhanced the $\mathrm{CO}_{2}$ emissions, as observed in the case of trellised Cabernet Sauvignon vines. Nitrification was the main soil microbiological process leading to the production of $\mathrm{N}_{2} \mathrm{O}$ in the studied soils, mostly due to the low soil moisture. The $\mathrm{N}_{2} \mathrm{O}$ emissions were greatest in the plot with bush vines, where the grape yield was lowest. In addition, the low water and mineral $\mathrm{N}$ contents of the soils and their coarse texture contribute to the relevance of these vineyard agrosystems as important sinks for atmospheric $\mathrm{CH}_{4}$. Considering the agronomic and environmental aspects in an integrated manner, the optimal vineyard management to ensure high grape yields and to improve the soil fertility with low greenhouse gas emissions were the use of compost in the drip-irrigated trellising vineyard with the grape variety Monastrell.

Overall, this work indicates that from a socio-environmental perspective, the use of organic amendments derived from the agro-food industry helps to close nutrient and energy loops, thus leading to a lower environmental impact of the food production sector within a regionally-based concept of the circular economy. The use of organic amendments should be analysed more deeply and generalised towards the sustainability of agro-food systems, particularly in semi-arid regions that are highly vulnerable to the impacts of regional and global climate changes. Therefore, more and longer studies than the present work are required to determine the active contributions of different agricultural variables to the mitigation of climate change in the ecosystems of Mediterranean climates. 
Author Contributions: Conceptualization. C.P., A.S.-C. and M.A.B.; methodology. A.M.-M., C.P., A.S.-C., M.A.B. and E.A.; software. C.P., A.M.-M. and E.A.; validation. C.P., A.S.-C. and M.A.B.; formal analysis. A.M.-M., M.A.B., C.P. and A.S.-C.; investigation. C.P., A.S.-C. and M.A.B.; resources. C.P. and A.S.-C.; data curation. C.P., A.S.-C. and A.M.-M.; writing-original draft preparation. C.P., A.S.-C. and A.M.-M.; writing-review and editing. C.P. and A.S.-C.; visualization. C.P., A.S.-C. and M.A.B.; supervision. C.P. and A.S.-C.; project administration. A.S.-C.; funding acquisition. A.S.-C. All authors have read and agreed to the published version of the manuscript.

Funding: This work has been financed by the Comunidad de Madrid and Technical University of Madrid (Spain) in the framework of the APOYO-JOVENES-NFW8ZQ-42-XE8B5K Project.

Acknowledgments: The authors thank the director of the winery "Santa Catalina del Mañán" (Monovar (Alicante)-Spain) for the use of the plots described in this work. Moreover, the authors acknowledge the linguistic revision of the manuscript performed by David Walker.

Conflicts of Interest: The authors declare no conflict of interest.

\section{References}

1. OIV. Databases and Statistics. Available online: http:// oiv.int/en/databases-and-statistics/statistics (accessed on 21 May 2020).

2. Sanz-Cobena, A.; Lassaletta, L.; Aguilera, E.; del Prado, A.; Garnier, J.; Billen, G.; Iglesias, A.; Sánchez, B.; Guardia, G.; Abalos, D.; et al. Strategies for greenhouse gas emissions mitigation in Mediterranean agriculture: A review. Agric. Ecosyst. Environ. 2017, 238, 5-24. [CrossRef]

3. INE. Industrial Products Survey. Available online: http://www.ine.es/dyngs/INEbase/es/operacion.htm?c=Estadistica_C\& cid $=1254736149053 \&$ menu $=$ resultados\&idp=1254735576715 (accessed on 21 May 2020).

4. Jones, G.V.; White, M.A.; Cooper, O.R.; Storchmann, K. Climate change and global wine quality. Clim. Chang. 2005, 73, 319-343. [CrossRef]

5. Celette, F.; Gary, C. Dynamics of water and nitrogen stress along the grapevine cycle as affected by cover cropping. Eur. J. Agron. 2013, 45, 142-152. [CrossRef]

6. Salomé, C.; Coll, P.; Lardo, E.; Metay, A.; Villenave, C.; Marsden, C.; Blanchart, E.; Hinsinger, P.; Le Cadre, E. The soil quality concept as a framework to assess management practices in vulnerable agroecosystems: A case study in Mediterranean vineyards. Ecol. Indic. 2016, 61, 456-465. [CrossRef]

7. Tomaz, A.; Coleto Martinez, J.M.; Arruda Pacheco, C. Yield and quality responses of 'Aragonez' grapevines under deficit irrigation and different soil management practices in a Mediterranean climate. Cienc. Tec. Vitivinicola 2015, 30, 9-20. [CrossRef]

8. Lardo, E.; Palese, A.M.; Nuzzo, V.; Xiloyannis, C.; Celano, G. Variability of total soil respiration in a Mediterranean vineyard. Soil Res. 2015, 53, 531-541. [CrossRef]

9. Cavallo, P.; Poni, S.; Rotundo, A. Ecophysiology and vine performance of cv. "Aglianico" under various training systems. Sci. Hortic. 2001, 87, 21-32. [CrossRef]

10. Coulouma, G.; Boizard, H.; Trotoux, G.; Lagacherie, P.; Richard, G. Effect of deep tillage for vineyard establishment on soil structure: A case study in Southern France. Soil Tillage Res. 2006, 88, 132-143. [CrossRef]

11. Pérez-Álvarez, E.P.; Martínez-Vidaurre, J.M.; Martín, I.; García-Escudero, E.; Peregrina, F. Relationships among soil nitrate nitrogen and nitrogen nutritional status, yield components, and must quality in semi-arid vineyards from Rioja AOC, Spain. Commun. Soil Sci. Plant Anal. 2013, 44, 232-242. [CrossRef]

12. Morlat, R.; Chaussod, R. Long-term additions of organic amendments in a Loire Valley vineyard. I. Effects on properties of a calcareous sandy soil. Am. J. Enol. Vitic. 2008, 59, 353-363.

13. Calleja-Cervantes, M.E.; Fernández-González, A.J.; Irigoyen, I.; Fernández-López, M.; Aparicio-Tejo, P.M.; Menéndez, S. Thirteen years of continued application of composted organic wastes in a vineyard modify soil quality characteristics. Soil Biol. Biochem. 2015, 90, 241-254. [CrossRef]

14. Aguilera, E.; Lassaletta, L.; Sanz-Cobena, A.; Garnier, J.; Vallejo, A. The potential of organic fertilizers and water management to reduce $\mathrm{N} 2 \mathrm{O}$ emissions in Mediterranean climate cropping systems. A review. Agric. Ecosyst. Environ. 2013, 164, 32-52. [CrossRef]

15. Garland, G.M.; Suddick, E.; Burger, M.; Horwath, W.R.; Six, J. Direct $\mathrm{N}_{2} \mathrm{O}$ emissions following transition from conventional till to no-till in a cover cropped Mediterranean vineyard (Vitis vinifera). Agric. Ecosyst. Environ. 2011, 141, 234-239. [CrossRef]

16. Shvaleva, A.; Lobo-do-Vale, R.; Cruz, C.; Castaldi, S.; Rosa, A.P.; Chaves, M.M.; Pereira, J.S. Soil-atmosphere greenhouse gases $\left(\mathrm{CO}_{2}, \mathrm{CH}_{4}\right.$ and $\left.\mathrm{N}_{2} \mathrm{O}\right)$ exchange in evergreen oak woodland in southern Portugal. Plant Soil Environ. 2011, 57, 471-477. [CrossRef]

17. Morell, F.J.; Álvaro-Fuentes, J.; Lampurlanés, J.; Cantero-Martínez, C. Soil $\mathrm{CO}_{2}$ fluxes following tillage and rainfall events in a semiarid Mediterranean agroecosystem: Effects of tillage systems and nitrogen fertilization. Agric. Ecosyst. Environ. 2010, 139, 167-173. [CrossRef]

18. Six, J.; Conant, R.T.; Paul, E.A.; Paustian, K. Stabilization mechanisms of soil organic matter. Implications for C-saturation of soils. Plant Soil 2002, 241, 155-176. [CrossRef] 
19. Cayuela, M.L.; Aguilera, E.; Sanz-Cobena, A.; Adams, D.C.; Abalos, D.; Barton, L.; Ryalsh, R.; Silver, W.L.; Alfaro, M.A.; Pappa, V.A.; et al. Direct nitrous oxide emissions in Mediterranean climate cropping systems: Emission factors based on a meta-analysis of available measurement data. Agric. Ecosyst. Environ. 2017, 238, 25-35. [CrossRef]

20. Prosdocimi, M.; Jordán, A.; Tarolli, P.; Keesstra, S.; Novara, A.; Cerdà, A. The immediate effectiveness of barley straw mulch in reducing soil erodibility and surface run-off generation in Mediterranean vineyards. Sci. Total Environ. 2016, 547, 323-330. [CrossRef]

21. Bustamante, M.A.; Said-Pullicino, D.; Agulló, E.; Andreu, J.; Paredes, C.; Moral, R. Application of winery and distillery waste composts to a Jumilla (SE Spain) vineyard: Effects on the characteristics of a calcareous sandy-loam soil. Agric. Ecosyst. Environ. 2011, 140, 80-87. [CrossRef]

22. Rubio, R.; Pérez-Murcia, M.D.; Agulló, E.; Bustamante, M.A.; Sánchez, C.; Paredes, C.; Moral, R. Recycling of agro-food wastes into vineyards by composting: Agronomic validation in field conditions. Commun. Soil Sci. Plant Anal. 2013, 44, 502-516. [CrossRef]

23. Peregrina, F.; Larrieta, C.; Colina, M.; Mariscal-Sancho, I.; Martín, I.; Martínez-Vidaurre, J.M.; García-Escudero, E. Spent mushroom substrates influence soil quality and nitrogen availability in a semiarid vineyard soil. Soil Sci. Soc. Am. J. 2012, 76, 1655-1666. [CrossRef]

24. Paradelo, R.; Moldes, A.B.; Barral, M.T. Carbon and nitrogen mineralization in a vineyard soil amended with grape marc vermicompost. Waste Manag. Res. 2011, 29, 1177-1184. [CrossRef] [PubMed]

25. Donia, E.; Mineo, A.M.; Sgroi, F. A methodological approach for assessing business investments in renewable resources from a circular economy perspective. Land Use Policy 2018, 76, 823-827. [CrossRef]

26. MAGRAMA. Agro-climatic information. Available online: http:/ / eportal.mapa.gob.es/websiar/Inicio.aspx (accessed on 22 May 2020). (In Spanish)

27. Soil Survey Staff. Keys to Soil Taxonomy, 12th ed.; USDA-Natural Resources Conservation Service: Washington, DC, USA, 2014.

28. Council Directive 91/676/EEC. Council Directive of 12 December 1991 concerning the protection of waters against pollution caused by nitrates from agricultural sources. Off. J. Eur. Communities 1991, 375, 1-8.

29. Medina, E.; Paredes, C.; Bustamante, M.A.; Moral, R.; Moreno-Caselles, J. Relationships between soil physico-chemical, chemical and biological properties in a soil amended with spent mushroom substrate. Geoderma 2012, 173-174, 152-161. [CrossRef]

30. Idrovo-Novillo, J.; Gavilanes-Terán, I.; Bustamante, M.A.; Paredes, C. Composting as a method to recycle renewable plant resources back to the ornamental plant industry: Agronomic and economic assessment of composts. Process Saf. Environ. Prot. 2018, 116, 388-395. [CrossRef]

31. Recio, J.; Vallejo, A.; Le-Noë, J.; Garnier, J.; García-Marco, S.; Álvarez, J.M.; Sanz-Cobena, A. The effect of nitrification inhibitors on $\mathrm{NH}_{3}$ and $\mathrm{N}_{2} \mathrm{O}$ emissions in highly $\mathrm{N}$ fertilized irrigated Mediterranean cropping systems. Sci. Total Environ. 2018, 636, 427-436. [CrossRef]

32. Arias-Navarro, C.; Díaz-Pinés, E.; Kiese, R.; Rosenstock, T.S.; Rufino, M.C.; Stern, D.; Neufeldt, H.; Verchot, L.V.; Butterbach-Bahl, K. Gas pooling: A sampling technique to overcome spatial heterogeneity of soil carbon dioxide and nitrous oxide fluxes. Soil Biol. Biochem. 2013, 67, 20-23. [CrossRef]

33. Abalos, D.; Sanz-Cobeña, A.; Garcia-Torres, L.; van Groenigen, J.W.; Vallejo, A. Role of maize stover incorporation on nitrogen oxide emissions in a non-irrigated Mediterranean barley field. Plant Soil 2012, 364, 357-371. [CrossRef]

34. Van Cleemput, O.; Boeckx, P. Greenhouse gas fluxes: Measurements. In Encyclopedia of Soil Science, 2nd ed.; Lal, R., Ed.; CRC Press: Boca Ratón, FL, USA, 2005; pp. 787-788.

35. Menéndez, S.; Merino, P.; Pinto, M.; González-Murua, C.; Estavillo, J.M. 3,4-Dimethylpyrazol phosphate effect on nitrous oxide, nitric oxide, ammonia, and carbon dioxide emissions from grasslands. J. Environ. Qual. 2006, 35, 973-981. [CrossRef]

36. Hannachi, N.; Cocco, S.; Fornasier, F.; Agnelli, A.; Brecciaroli, G.; Massaccesi, L.; Weindorf, D.; Corti, G. Effects of cultivation on chemical and biochemical properties of dryland soils from southern Tunisia. Agric. Ecosyst. Environ. 2015, 199, 249-260. [CrossRef]

37. Bustamante, M.A.; Said-Pullicino, D.; Paredes, C.; Cecilia, J.A.; Moral, R. Influences of winery—distillery waste compost stability and soil type on soil carbon dynamics in amended soils. Waste Manag. 2010, 30, 1966-1975. [CrossRef]

38. Stockmann, U.; Adams, M.A.; Crawford, J.W.; Field, D.J.; Henakaarchchi, N.; Jenkins, M.; Minasny, B.; McBratney, A.B.; de Remy de Courcelles, V.; Singh, K.; et al. The knowns, known unknowns and unknowns of sequestration of soil organic carbon. Agric. Ecosyst. Environ. 2013, 164, 80-99. [CrossRef]

39. Paredes, C.; Barber, X.; Marín-Martínez, A.; Bustamante, M.A.; Pérez-Murcia, M.D.; Pérez-Espinosa, A.; Agulló, E.; Aguilar, D.; Moral, R. Hierarchical bayesian spatial modelling to identify and map spatial variations of soil properties in vitivinicultural zoning studies. In Proceedings of the 8th European Congress on Regional Geoscientific, Cartographic and Information Systems, Barcelona, Spain, 15-17 June 2015; pp. 195-196.

40. Steenwerth, K.; Belina, K.M. Cover crops and cultivation: Impacts on soil N dynamics and microbiological function in a Mediterranean vineyard agroecosystem. Appl. Soil Ecol. 2008, 40, 370-380. [CrossRef]

41. Vázquez, N.; Pardo, A.; Suso, M.L.; Quemada, M. Drainage and nitrate leaching under processing tomato growth with drip irrigation and plastic mulching. Agric. Ecosyst. Environ. 2006, 112, 313-323. [CrossRef]

42. Christou, M.; Avramides, E.J.; Jones, D.L. Dissolved organic nitrogen dynamics in a Mediterranean vineyard soil. Soil Biol. Biochem. 2006, 38, 2265-2277. [CrossRef] 
43. Romero, P.; Pérez-Pérez, J.G.; del Amor, F.; Martínez-Cutillas, A.; Dodd, I.C.; Botía, P. Partial root zone drying exerts different physiological responses on field-grown grapevine (Vitis vinifera cv. Monastrell) in comparison to regulated deficit irrigation. Funct. Plant Biol. 2014, 41, 1087-1106. [CrossRef]

44. Meijide, A.; Díez, J.A.; Sánchez-Martín, L.; López-Fernández, S.; Vallejo, A. Nitrogen oxide emissions from an irrigated maize crop amended with treated pig slurries and composts in a Mediterranean climate. Agric. Ecosyst. Environ. 2007, 121, 383-394. [CrossRef]

45. Heller, H.; Bar-Tal, A.; Tamir, G.; Bloom, P.; Venterea, R.T.; Chen, D.; Zhang, Y.; Clapp, C.E.; Fine, P. Effects of manure and cultivation on carbon dioxide and nitrous oxide emissions from a corn field under Mediterranean conditions. J. Environ. Qual. 2010, 39, 437-448. [CrossRef] [PubMed]

46. Tatti, E.; Goyer, C.; Zebarth, B.J.; Burton, D.L.; Giovannetti, L.; Viti, C. Short-term effects of mineral and organic fertilizer on denitrifiers, nitrous oxide emissions and denitrification in long-term amended vineyard soils. Soil Sci. Soc. Am. J. 2012, 77, 113-122. [CrossRef]

47. Beare, M.H.; Gregorich, E.G.; St-Georges, P. Compaction effects on $\mathrm{CO}_{2}$ and $\mathrm{N}_{2} \mathrm{O}$ production during drying and rewetting of soil. Soil Biol. Biochem. 2009, 41, 611-621. [CrossRef]

48. Galbally, I.E.; Kirstine, W.V.; Meyer, C.P.; Wang, Y.P. Soil-atmosphere trace gas exchange in semiarid and arid zones. J. Environ. Qual. 2008, 37, 599-607. [CrossRef] [PubMed]

49. Ku, H.H.; Hayashi, K.; Agbisit, R.; Villegas-Pangga, G. Effect of calcium silicate on nutrient use of lowland rice and greenhouse gas emission from a paddy soil under alternating wetting and drying. Pedosphere 2020, 30, 535-543. [CrossRef]

50. Otter, L.B.; Scholes, M.C. Methane sources and sinks in a periodically flooded South African savanna. Glob. Biogeochem. Cycles. 2000, 14, 97-111. [CrossRef]

51. Le Mer, J.; Roger, P. Production, oxidation, emission and consumption of methane by soils: A review. Eur. J. Soil Sci. 2001, 37, 25-50. [CrossRef]

52. Bowden, R.D.; Rullo, G.; Stevens, G.R.; Steudler, P.A. Soil fluxes of carbon dioxide, nitrous oxide, and methane at a productive temperate deciduous forest. J. Environ. Qual. 2000, 29, 268-276. [CrossRef]

53. Huang, Y.; Zou, J.; Zheng, X.; Wang, Y.; Xu, X. Nitrous oxide emissions as influenced by amendment of plant residues with different C:N ratios. Soil Biol. Biochem. 2004, 36, 973-981. [CrossRef]

54. de Urzedo, D.; Pires-Franco, M.; Machado-Pitombo, L.; Braga do Carmo, J. Effects of organic and inorganic fertilizers on greenhouse gas (GHG) emissions in tropical forestry. For. Ecol. Manag. 2013, 23, 46-59. [CrossRef]

55. Ryals, R.; Silver, W.L. Effects of organic matter amendments on net primary productivity and greenhouse gas emissions in annual grasslands. Ecol. Appl. 2013, 23, 46-59. [CrossRef] [PubMed] 